\title{
Rethinking Marketing Programs for Emerging Markets
}

\author{
By: Niraj Dawar and Amitava Chattopadhyay
}

Working Paper Number 320

June 2000 


\section{Rethinking Marketing Programs for Emerging Markets}

Niraj Dawar and Amitava Chattopadhyay

\footnotetext{
* Niraj Dawar is Associate Professor of Marketing and Walter A. Thompson Faculty Fellow at the Richard Ivey School of Business, University of Western Ontario, Canada. Amitava Chattopadhyay is the L'Oreal Chaired Professor of Marketing-Innovation and Creativity, INSEAD, France. Niraj Dawar gratefully acknowledges the support of a research grant from the Richard Ivey School of Business and a visiting professorship at William Davidson Institute at the University of Michigan Business School. Amitava Chattopadhyay gratefully acknowledges the financial support from the R\&D Department at INSEAD, during the writing of this paper.
} 


\title{
Rethinking Marketing Programs for Emerging Markets
}

\begin{abstract}
We point to a fundamental inconsistency in the emerging market strategies of multinational firms. On the one hand, they seek billions of new consumers in the emerging markets of China, India, Indonesia, and Latin America; on the other, their marketing programs are scarcely adapted for these markets. The result is low market penetration, low market shares, and poor profitability. These multinationals are trapped by their own devices in gilded cages, serving the affluent few and ignoring the potential of billions of new consumers that attracted them in the first place. In this paper, we propose that, in order to attract billions of new consumers, the marketing programs of multinationals need to be rethought from the ground up. We identify three key factors that characterize emerging markets: (1) low incomes, (2) variability in consumers and infrastructure, and (3) the relative cheapness of labor, which is often substituted for capital. We draw on numerous case studies from around the world to illustrate how to incorporate these realities into marketing programs. We conclude with a discussion of the implications of such an approach for the multinational's core strategic assumptions.
\end{abstract}

Keywords: Marketing, Emerging market consumers, Consumer Behavior, Multinationals 


\section{Rethinking Marketing Programs for Emerging Markets}

\subsection{Introduction}

Lured by the prospect of one billion breakfast eaters, Kellogg, the U.S. cereals giant, ventured into India in the mid-1990s. Three years after entering the market, sales stood at an unimpressive $\$ 10$ million. Indian consumers were not sold on breakfast cereals. Most consumers either prepared breakfast from scratch every morning, or grabbed some biscuits with tea at a roadside tea stall. Advertising positions common in the west, such as the convenience of breakfast cereal, did not resonate with the mass market. Segments of the market that did find the convenience positioning appealing were unable to afford the international prices of Kellogg's brands. Disappointing results led the company to re-examine its approach. Last year Kellogg finally realigned its marketing to suit local market conditions: they introduced a range of breakfast biscuits under the Chocos brand name. Priced at Rs. 5 (10 U.S. cents) for a 50-gram pack, and with extensive distribution coverage that includes roadside tea stalls, they are targeted at the mass market and expected to generate large sales volumes.

Like Kellogg, many multinationals rushed in to emerging markets over the past decade, agog at the potential of billions of new consumers who had been liberated from planned economies and protectionist barriers. But as the initial euphoria wanes, there is a growing realization that the billions of consumers have not reciprocated the multinationals' embrace; that local competitors are stronger than expected; and competition for the top tier of the market is fierce, as major players from around the world compete for the same limited pie. Multinationals' stance is rapidly evolving from one of "exploration," "investment," and "establishing a beachhead," to more prosaic reasons such as "generating a return," "growing long term sales volume," and "building a dominant position." Local subsidiaries are being called to account, and losses that may earlier have been viewed as investments 
in market building, are no longer tolerated. Local operations now realize that the three to five percent of consumers in emerging markets who have global preferences and purchasing power no longer suffice as the only target market. Instead, they must delve deeper into the local consumer base in order to deliver on the promise of tapping into billion-consumer markets. ${ }^{\square}$ This calls for a shift in emphasis from the "global" to the "local" consumer, and from globally standardized to locally adapted marketing programs.

Most multinationals have long resisted targeting the local consumer, preferring instead to transplant offerings that were developed for their traditional developed markets. ${ }^{6}$ Three reasons are often cited for the reticance to localize. First, it is argued that the mass market any single emerging economy is not large enough to justify the effort and cost of localization. Second, multinational managers rationalize, emerging market consumers are growing more affluent by the day and are becoming more like their affluent-market counterparts in terms of preferences and purchasing power. As a result, they argue, they are better off offering globally standardized products and waiting for the consumers to evolve towards these. Finally, it is argued that to adapt to local market conditions in every emerging economy will undermine core assumptions about standardization that are fundamental to the success of multinationals. These are powerful arguments, but they do not stand up to scrutiny.

That emerging markets are considered small is a self-fulfilling prophecy. Products and programs transplanted from affluent markets only appeal to the affluent elite: no more than five per cent of the population. Delving deeper into the consumer base to establish mass-market positions would create the economies of scale necessary to justify localization. And localization along characteristics that are common across emerging markets, allows the costs to be spread over much larger volumes. Emerging market veterans such as Unilever, Colgate Palmolive, and South African Breweries have amply demonstrated the viability of mass markets in emerging economies, as well as the benefits of rapidly transferring knowledge gained in one emerging market to others. 
The second argument, that emerging market consumers are rapidly becoming more like their affluent market counterparts, is true. But the rate of change is not as rapid as contended. In most emerging markets, the mass market will remain poor well beyond the current planning horizons of most multinationals. And even as they grow more affluent, it is far from certain that Chinese and Indian consumers' preferences will converge with those of Europeans or Americans. It is as likely that they may retain idiosyncratic local consumption patterns, driven by cultural norms. A better strategy for any serious emerging market player is to understand and cater to local consumers' current needs, and evolve with them, as they grow more affluent.

The final reason offered is that localization is counter to core assumptions about global standardization. For example, at the marketing level, conventional wisdom for developed markets has it that successful firms fragment the market into ever finer segments, rapidly develop and deploy innovative new products, cajole and co-opt powerful distributors to gain access to consumers, and position their brands to exact premium prices for their offerings. These practices are so central to the strategy of many developed market companies, that they are embedded in the culture of these organizations. Replication of these practices across international markets is considered key to multinationals' success. Yet, conditions in emerging markets challenge these assumptions and call for very different marketing programs. ${ }^{\text {B }}$ Can multinationals take advantage of the opportunities afforded by the mass markets of emerging economies without forsaking the presumed bases of their success in developed markets? We suggest that the initial difficulties faced by many multinationals as they have entered emerging markets can be ascribed to attempts to transfer, without translation, their conventional marketing practices. ${ }^{4}$ Multinationals can choose to maintain their standardized approach only at the cost of being bit- players in emerging markets.

Our objective in this article is to demonstrate how the emerging market environment calls into question received marketing wisdom, and to draw lessons from companies that have designed marketing programs from the ground up. Specifically, we look at three fundamental characteristics 
of emerging market environments: (1) low per capita income and its impact on consumer behavior, (2) immense variability in consumers and infrastructure, and (3) relative cheapness of labor, which is often substituted for capital by both companies and consumers. These characteristics have profound implications for the conceptualization and implementation of marketing programs. We organize our discussion of the effects of each of these fundamental differences around the central pillars of marketing: segmentation and the key program ingredients of product, price, distribution, and communication. Figure 1 summarizes the framework and the main arguments.

\section{$\underline{2.0 \text { Low Incomes }}$}

Multinationals bring to emerging markets not just their products, technology, and skills, but also implicitly, their understanding of market structures from developed-country contexts. Assumptions about the similarity of consumer preferences and buyer behavior, segments, and arguments about scale economies justify thewholesale import of marketing programs from developed markets. But these marketing programs are not matched to the needs of the market.

\subsection{Coarse Segments that are Difficult to Reach}

At the root of the mismatch are fundamental assumptions about market segmentation. The fine-grained segmentation of developed markets is predicated on the low costs of and high returns on segmentation. Take the example of soap brands. In developed markets the hundreds of brands on the shelf offer a vast choice of finely differentiated benefits on dimensions such as fragrance, freshness, skin type, naturalness, softness, gentleness, lather, anti-aging, and many others. Segmentation at such fine levels is expensive in terms of product development, branding, and distribution costs. These costs are justified if consumers are both able and willing to pay for specialized products, which they perceive to better meet their needs. But the mass market in emerging economies is unable to afford this level of segmentation. Segments there are far coarser than those to which multinationals are accustomed. In Indonesia, $88 \%$ of the soap market is classified as "regular" soap, with another $11 \%$ 
accounted for by deodorant soap, and the remaining $1 \%$ is moisturizing soap. The average price of soap sold in Indonesia is less than one third of that in the United States.

The fine level of segmentation also assumes that market segments can be easily reached through differentiated communications, targeted at different audiences. Targeted media that allow fine segmentation are simply unavailable in many emerging markets. Consider the example of magazines: there exist about 18,000 magazine titles in the United States for a population of 250 million. In contrast, in Brazil, a country of 150 million, there are fewer than one thousand magazines and, in India, a country of one billion people, there exist just over 300 magazine titles. The lack of narrowly focused media limit the ability of marketers to segment their markets, and increase the effective cost per hit of advertisements. A smaller proportion of readers of any given title is likely to be in the target market for a given product.

\subsection{Basic, Functional, Long-Lasting Products}

Some local and international firms have amply demonstrated that through well targeted, indigenously developed, and locally produced products, mass markets can yield serious profits. One lesson from these companies is that rapid new product development and deployment, continuous product innovation, and accelerated obsolescence that are part of the competitive apparatus in developed markets, are unsuited to emerging markets. Here, consumers dislike products that evolve too rapidly, making their recent purchases obsolete. Instead, the need is for basic, functional, long lasting products. The Volkswagen Beetle remained the largest selling car in Brazil long after it had been phased out of the affluent markets, and despite competitive assaults by other manufacturers with newer models. The largest selling car in China is still the Volkswagen Santana, a model that was phased out of developed markets 15 years ago. These cars are known to be dependable workhorses that can be easily repaired when they break down, with readily available and inexpensive spare parts. 


\subsection{Price Logic Dominates}

\subsubsection{Reverse PPP}

Prices need to be established in the context of local consumers' purchasing power, rather than in relation to international standards. Purchasing Power Parity (PPP) exchange rates estimate the value of a currency in terms of the basket of goods that it buys (compared with the cost of a similar basket in a reference country and currency) rather than in terms of the existing market exchange rates. By this measure, most emerging market currencies are severely undervalued relative to hard currencies, meaning that they actually buy more than one would expect, given the market exchange rate. International firms are attracted to many emerging markets precisely because of the size of the market in PPP terms. One firm found, for example, that in China the number of consumers in the $\$ 10,000$ to $\$ 40,000$ income range is less than 3 million at market exchange rates, but over 80 million at PPP rates. But firms often fail to recognize that this large potential market is only accessible if product prices are established relative to local purchasing power rather than by converting international prices at market exchange rates. In other words, international firms need to work backwards from the PPP numbers to price their products. The practice of using market exchange rates translates into overpriced products, making them accessible to only the wealthiest. For example, the PPP of the RMB in China is estimated at close to 4 to the US dollar, while the market exchange rate is over RMB 8 to the US dollar. A product that sells in the United States for $\$ 10$ will be priced using the market exchange rate at RMB 80. In reverse PPP terms, this is the equivalent of pricing the product at \$20. Firms cannot have it both ways: expectations of large PPP-based markets, with products priced using market exchange rates.

South African Breweries (SAB) is one of the rare foreign breweries that is profitable in China. SAB's approach to the China market has been markedly different from that of the fifty other international brewers operating there. SAB brews and sells local brands of beer, has consciously targeted the mass market, and has avoided the crowded premium urban segments. The price of its 
brands is up to $70 \%$ lower than that of international brands such as Budweiser or Carlsberg. But SAB's long term strategy of building market share is paying off. Despite its limited reach, which currently covers less than five per cent of the market, it is the third largest brewer in China. It has a dominant market share, in every provincial market in China, in which it competes.

\subsubsection{High Savings Rates}

High savings rates, too, confound multinationals' expectations of market size. A common assumption is that high savings rates in emerging markets stem from the lack of purchase options, but that once firms introduce consumption choices, savings will give way to consumption. While this is true to some extent, the rate of conversion from savings to consumption has been slow. High savings rates are due to the lack of an institutionalized social net (unemployment insurance, retirement and disability benefits, etc.). This encourages what in the west is called a "depression era mentality," that discourages profligacy. People save for a "rainy day" when they may be laid off, for retirement, for medical expenses, and for family obligations. Often, these social and family obligations for savings are driven by strong cultural norms. Consumption options do not easily compete with these reasons for saving.

\subsubsection{Volumes Drive Profits, Not Margins.}

Strategies that favor thin margins and rely on large volumes tend to succeed. Pricing logic needs to dominate marketing programs and drive product, packaging, distribution, and communication decisions. Unilever's Lifebuoy brand of soap, popular in Africa, India, and Indonesia is priced low and made using inexpensive local ingredients and packaging material. By volume, Lifebuoy is the largest selling brand of soap in the world.

Large volumes can make even trivially priced products profitable. Cadbury's knows that Indian consumers are willing to pay about one cent for an impulse purchase candy. The company delivers packs of these candies to retailers who then break the bulk and sell the candy by the unit. Cadbury's international managers question why their company should spend time, effort, and money 
selling products that retail at one cent. But in this market, it is the enormous volumes, not the margins that drive profitability. If $10 \%$ of the population were to buy just one candy a week, annual sales would exceed $\$ 60$ million. An added advantage is that the inexpensive candy maintains a shelf presence for the brand and provides an entry-level item that converts some consumers on to higher priced and higher margin products.

\subsection{Distribution: Trade Marketing, One Store at a Time}

\subsubsection{International Retailers are Not the Solution}

In contrast to the highly concentrated retail and distribution industry in developed markets, the retail trade in emerging markets is extremely fragmented. While major international retail chains such as Ahold, Carrefour, Nanz, Metro, and Walmart operate in many emerging markets, they have yet to develop a retail format that has mass. Overall, chain stores account for less then $3 \%$ by value of the retail market in China.

Multinationals sometimes rely on these chains as their primary channel. But, it is unlikely, that chains will provide access to mass markets. High population density, small homes with little space for storage, lack of refrigeration, and low automobile ownership means that consumers buy daily and locally. As a result, retail outlet density has to be very high. Retail formats from developed countries cannot deliver economically, under these conditions. Therefore, foreign distributors cannot be the sole pillar of any mass-market distribution strategy.

\subsubsection{Building a Multilayered Distribution System}

At the same time, using the small independently owned stores poses a serious challenge to many international firms, as they lack the expertise to deal with a fragmented trade. It is estimated that there are 9 million small independently owned grocery shops in China that have limited working capital and, typically, occupy fewer than 300 square feet. To access even the first tier of these outlets, and to establish a brand presence on the shelf, large, dedicated sales forces, and large amounts of working capital are required. Beyond the first tier of retail outlets, many companies use multiple 
levels of wholesalers and distributors to capture shelf space one store at a time. The multilayered distribution channel of course puts a large distance between mass markets (especially rural markets) and manufacturers, impeding learning and marketing adaptation. Notwithstanding the challenges, some international firms, that have had a long presence in emerging markets, have successfully developed effective distribution systems. Unilever's distribution network in India, which provides it with a formidable barrier to entry, serves over 800,000 retail outlets directly, and relies on wholesalers and distributors to reach another 3.5 million.

\subsubsection{Channel Power}

Despite being fragmented, however, the trade has considerable power. Store formats do not allow consumers to browse. Typically, the consumer interacts directly with the retail salesperson (often the owner), whose recommendations carry weight. The owner's relationship with consumers is based on an understanding of their needs and buying habits, and cemented by the retailer extending credit. These relationships give the trade tremendous clout in brand recommendations, making trade marketing an essential element of any manufacturer's program. Building relationships with a fragmented trade requires an understanding of their interests. For example, it is counterproductive to push inventory on them, given their tight working capital positions. Rather, successful manufacturers creatively develop new revenue activities for the retailer. United Phosphorous Limited (UPL), an Indian crop protection company, realized that in its rural markets small farmers were not applying pesticide at all, or applying it inappropriately due to the lack of application equipment. The capital cost of the equipment (mounted pumps and dispensers that cost up to \$3000) placed it out of reach of small farmers and most rural retailers. UPL designed a program in which it arranged for bank loans for its rural retailers to purchase application equipment, and demonstrated to these retailers the additional revenue possibilities from renting this equipment to small farmers. The result was an added revenue stream for rural retailers and additional sales of pesticides for UPL. 


\subsection{Communication: Selling Users and Non-Users on Product Benefits}

Lack of focused media creates coarse segments comprised of diverse consumers. In this environment, broad-based brand positions that are likely to appeal to a variety of people are more cost-effective than finely differentiated ones. Broad-based positions often need to be targeted to consumers who have not previously consumed the product or who are unfamiliar with the benefits of the product. For example, offering the benefit of a shampoo-and-conditioner-in-one is of little relevance where consumers have never used conditioner, or for that matter, shampoo. The task of communication is to position these products on the basis of broad-based consumer needs. Kellogg, for example, has developed a "nutritious breakfast" positioning in India, based on research on school children that shows they are not getting their recommended daily doses of some ingredients.

Once the brand positioning is established, the communication focus shifts to increasing the low rates of product use in emerging markets. A key communication decision, therefore, is whether to target existing consumers to consume more, or to draw non-consumers into the market. Typically, multinationals choose to target existing consumers. International brewers in China, for example, have chosen to focus on the Shanghai and other urban markets where per capita consumption is already high. The reasoning is that it is easier to convince an existing beer drinker to have another beer, than to convert someone who has never drunk beer to try one. The existing product portfolios of multinationals, however, often drive this reasoning. It is easier to sell more of an existing product to current consumers than to develop new products and brands to appeal to non-consumers. But some multinationals are not averse to seizing local opportunities. Just as Kellogg realized that biscuits were the way into the Indian consumers' breakfast diet, Coca-Cola has found that to gain share of throat in China and Russia, products that fit with local consumption habits were required. The company has introduced fruit-flavored tea in China and low priced carbonated fruit flavored drinks in Russia. 


\section{$\underline{\text { 3.0 Variability }}$}

Challenges due to low incomes are compounded by variability among consumers and in the infrastructure. Consumers in Indonesia, China, and India are diverse along cultural, religious, and linguistic dimensions, but in this respect, these continent sized countries are no different than, say, Europe. More specific to emerging markets is variability of income and, super-imposed on it, variability in income flow, which arises from the different pay schedules: from hourly or daily wages, to monthly paychecks. The sharp urban-rural divide is correlated with income differences, with urban areas containing islands of prosperity. The second source of variability is the variability in the transportation, telecommunications, power, and financial infrastructure in emerging markets. A delivery by road may take anywhere between one day to three days, over a distance of 200 miles. A rainfall can throw the telephone infrastructure into chaos. Manufacturers often generate electricity in-house because the grid is subject to frequent power outages. A bank check may clear in three days, or it may take several weeks.

\subsection{Segmentation: Income and Income Flow Variability}

\section{$\underline{\text { 3.1.1 Income Variability }}$}

Large disparities in consumers' incomes imply the existence of multiple segments with very different levels of purchasing power. Segments that vary in income allow some savvy firms to create innovative opportunities. The local distributor for Akai in India, Baron International, realized that the market for new television sets was primarily urban. However, there was considerable inertia when it came to replacing a working television set of a previous generation. But Baron also knew that there existed a market, primarily rural, for used television sets. The company instituted a tradein scheme that linked urban retailers with those in rural areas. Rural retailers purchased traded-in sets from urban dealers. Urban consumers got something for their old TV sets, urban retailers made their margins from selling the traded-in sets, rural retailers made a profit on used TVs, and rural 
consumers were offered television sets they could afford. Baron's sales increased $1500 \%$ over three years, making it the most profitable firm in the television business.

\subsubsection{Income Flow Variability}

Superimposed on the dimension of income variability is variability in income flow. A significant proportion of the working population in emerging markets is paid daily wages, a practice practically non-existent in developed markets. Daily wage earners tend to have little stock of money, only a flow. Consequently, they tend to make purchases only to meet their daily needs, and have little capacity to build inventory. The marketing implications are far-reaching. Not only are pack sizes, and price points affected, but it turns out that consumers' trade-off purchases across a much wider array of product categories. As a result, the nature of competition for any given product is much broader. A manufacturer of soft drinks competes not just with other soft drink manufacturers, but with a broad set of purchases that the consumer considers 'treats.'

\subsection{Product: Design and Package for Variability}

Variability of the infrastructure is tangibly manifest in the quality of products that arrive on the market. They have been through a sourcing, production, and delivery system that at every stage was subject to non standardized treatment. Delivering on the central promise of branding, consistent quality over time, is a difficult task in such an environment. But it is precisely this variability in the environment that puts a premium on brands that are able to deliver consistency. Marico, an Indian edible oil company, has found that rural consumers in the interior of India willingly pay a reasonable price premium for branded cooking oil, over commodity oil, because they are certain of its consistent quality. Unbranded products are often adulterated and of uncertain quality.

In order to deliver consistent quality, products need to be designed to cope with variability. Typically, products from developed markets are designed for fairly standardized usage and handling conditions, and do not tolerate wide environmental variance. For example, washing machines in emerging markets need to be designed for power and water outages. Whirlpool found that, in India, 
its machines needed to be designed to restart from the point in the washing cycle where they had left off when the power and/or water was interrupted, rather than return to the start as they are designed to do in developed markets where uninterrupted power and water supply are taken for granted.

Variability in consumer incomes and income flow requires a product portfolio that addresses the needs of different segments without adding to costs. Offering a variety of pack sizes at different price points is one solution. Cooking oil, for example, is sold in single use sachets of five $\mathrm{ml}$ for the daily purchaser, as well as in large 10-liter containers. But a variety of pack sizes can also have unforeseen consequences. For example, if the family-pack size is priced at a sufficient quantity discount over smaller packs, enterprising street traders will purchase the large pack and retail it in loose form. Though, this form of informal retailing allows greater market penetration, it also means that the company can loose control over the quality of the product, brand presentation, and pricing. One solution is to price the different pack sizes to discourage unintended arbitrage, i.e.; quantity discounts cannot be large.

\subsection{Price: Don't Price Promote - Saturate Price Points}

In an occasional effort to capture volume sales, multinational brands use price promotions. Often, such price promotions yield dramatic, if temporary, sales increases. These large volume increases reveal a potentially large market that remains untapped, just below the actual price points. To penetrate this market and generate sustainable volume sales, a permanent product entry at the lower price point is required. Failure to recognize the potentially huge market that lies below the surface of international price points can even place the premium, branded business at risk. By the mid-1990s Sony and Matsushita had captured 75\% of the top end of the Chinese market for televisions with sales of 1.5 million units. But this left the door open to local manufacturers Changhong, Konka, and Panda who achieved significant economies of scale by catering to the mass

market. Together these manufacturers sold over 5 million units. ${ }^{\text {G }}$ They then used their strong position to attack Japanese manufacturers in the higher priced segments. 


\subsection{Distribution: Brand Assortment and First Movers}

Despite similar outward appearances (small owner-run shops, with limited working capital whose primary selling point is the convenience of their location) there is considerable variability in the trade. In particular, urban and rural retailers tend to be run on different principles. In urban areas, these small retailers generally carry a surprisingly wide selection of brands in each product category. They are able to achieve this despite limited shelf space and inventory by rapidly turning over their stocks. Manufacturers and wholesalers make several deliveries every day to these small stores to maintain inventory levels. In this environment, remaining on the shelf, developing a differentiated position, and creating brand loyalty are keys to survival.

In contrast, rural retailers are also less specialized and carry a wider range of products. Since frequent deliveries are not possible, they tend to carry only a single brand in each product category. In this environment, being first on the shelf, and developing a privileged relationship with the retailer is a competitive advantage. Many brands that are first on the shelf become synonymous with the product category, and are difficult to dislodge. ${ }^{6}$ Maggi noodles, the brand that created the category of instant noodles in many emerging markets, remains the leader.

\subsection{Communication: Diverse and Fickle Audience}

Consumers in emerging markets shop daily and have 365 opportunities a year to switch brands, while the weekly purchasers in developed markets have 52. Attempts to reach emerging market consumers even once during the short purchase cycle, to ensure repeat purchase, make point of purchase advertising and trade push indispensable. This requires a significant reorientation in the allocation of funds across media. For example, outdoor advertising accounts for over $7 \%$ of all media expenditures in India, while it only accounts for $0.8 \%$ in the United States.

Mass media, the mainstay of communication efforts in developed markets, are also less effective in emerging markets. Large proportions of the population live in rural areas, distributed across vast distances in small isolated groups, with limited access to broadcast media. The existence 
of a multiplicity of languages (several hundred in large countries), and varying levels of illiteracy complicates the task of communication further. To overcome some of these challenges, Unilever pioneered the concept of the video van. Unilever's video vans travel from village to village screening films in the local language, interspersed with advertisements for Unilever products. The company also provides product usage demonstrations to the captive audience because written instructions on the pack may not be read by consumers who are either illiterate or do not understand the dialect.

Where mass media are used, variability can throw a spanner in the works. On reentering India in the 1990s, Coca Cola decided to invest massively on a Television advertising campaign. It invested in slick commercials, rich in color, with high production values, but the effect was somewhat lost on a market where $60 \%$ of all TVs are still black and white.

\subsection{Labor Substitution}

Labor-saving benefits are fundamental to the positioning of practically every product in developed markets. Dishwashing detergents, prepared foods, and household appliances, all promise the consumer less time and effort expenditures. But labor is cheap in emerging markets, and this leads to trade-offs that would be unusual in developed markets.

\subsection{Segments and Segmentability on Opportunity Cost of Time}

While the opportunity cost of time is low for the vast majority of consumers, for a small but significant segment, the opportunity cost of time is high. For this small segment, products that save labor might be thought to be attractive. But, segmenting the market on opportunity cost of time is not useful because, in most instances, time can be bought. Richer consumers substitute others' time for theirs, and the market for time-savings is served through inexpensive services rather than products. Premium-priced, non-stick cookware from Dupont have little appeal if consumers who can 
afford them generally rely on hired help for cooking and cleaning. In China, Dupont has struggled to expand market share beyond $2 \%$ of the market.

This does not mean that the products themselves are not viable in emerging markets, just that they need to be positioned differently. For example, fast food is popular not because it is fast, but because it is trendy. Similarly, washing machines may not have much appeal as labor savers when consumers who can afford household appliances are accustomed to hiring people to do their laundry by hand. But the machines can be positioned as reliable (hired help is often not), or on the basis of performance (machines do a better job). These benefits complement rather than compete with inexpensive labor. Sometimes consumers will both buy a washing machine and hire someone to operate it.

\subsection{Product: Substitute Capital with Consumers' Labor}

Careful consideration of the value of the various elements of the augmented product marketed by international firms often reveals that the firm's cost of creating some of the benefits offered is higher than its value to the emerging market consumer. Engaging the consumers' time and energy as a substitute can allow the firm to market the product at an affordable price to the mass market. For example, dairies in several Indian cities have opted to eliminate individual level packaging for milk. Instead, milk is distributed through vending machines where consumers bring their own containers to carry the milk home. Similarly, Whirlpool discovered that it was unable to sell its high priced, fully automatic machines in the emerging markets. It was only after it introduced twin-tub machines that were cheaper and utilized the consumers' labor rather than electronics to complete the entire washing cycle that sales took off. Interestingly, due to the fact that these machines had long disappeared in the developed markets, Whirlpool had to acquire the 'obsolete' technology from Korea. 


\subsection{Price: Make or Buy}

Buying decisions depend on consumers' assessments of the value of buying a product versus making it themselves. For example, consumers in developed countries are increasingly buying rather than making what they consume. Buy versus make trends are due to the high opportunity cost of consumers' own time, the economies of mass manufacture, and low transportation costs. With the low cost of time, and the relatively high cost of manufacture and transportation (capital intensive activities) in emerging markets, many products and services can be produced less expensively at home than manufactured goods. Less than $1 \%$ of the food consumed in India is pre-processed compared to over $95 \%$ in a developed country such as Japan. To motivate consumers in emerging markets, to buy rather than make products, the product or service must be priced competitively with homemade products, or must offer a benefit not easily incorporated in to homemade products.

\subsection{Distribution: People Power}

Developed markets have clearly moved towards heavily capital-intensive distribution with the introduction of electronic data interchanges, mechanized movement and monitoring of goods, and vending machines that replace salespeople. By contrast labor-intensive distribution remains economical in emerging markets. For example, in emerging markets, Coca-Cola has not invested in vending machines. These are too expensive relative to salespeople. In China, instead of vending machines, the company has experimented with a pushcart program in which salespeople dispense the company's drinks by the single-serve bottle. Sales of two cases (48 bottles) every day at US\$ 0.25 per bottle are sufficient to justify the costs of a salesperson. Similarly, in India, almost 10\% of CocaCola sales take place through fountains, where a salesperson dispenses drinks by the paper cup. Daily sales of as little as 100 cups justify the cost of the fountain and the person employed to dispense the drinks.

Modern retail formats such as supermarkets (e.g., Nanz), hypermarkets (e.g., Carrefour), and discount stores (e.g., Walmart), that substitute capital for labor, have experienced slow growth in 
emerging markets. The scale economies of these operations are offset by the high capital costs, and often lead to higher prices relative to small owner-operated stores. The typical $25 \%$ to $40 \%$ margins taken by international retailers reflect their higher operating costs relative to low-overhead local retailers, whose margins rarely exceed $15 \%$ with operating costs below five per cent of retail price.

\subsection{Communication: Interactive Customization without Technology}

The heavy reliance on mass communication in developed markets is based on the premise that delivering a message through a medium such as television or magazines is less expensive than delivering it through face to face contact. But in emerging markets, the face-to-face method has always been more economical. When Citibank launched its credit card in Asia, it found that in many markets the cost per customer of door-to-door sales was lower than a range of mass media, including magazine inserts, direct-mail, and take-one application forms placed on sales counters. 8 Personal selling also allows for more customized and interactive messages to be delivered to the customer. A characteristic important at an early stage in a product's life-cycle, such as credit cards in Asia at the time, leading to better conversion rates than, say, television advertising.

\section{$\underline{5.0 \text { Conclusions }}$}

The billions of consumers that multinationals seek in emerging economies will remain an elusive target unless these firms are able to develop value propositions that appeal to the mass market. For these firms, it should be abundantly clear that mass markets in emerging countries are unlike any markets they have traditionally served. The emerging market consumers' behavior is molded by low incomes, infrastructural variability, and the unique trade-offs created by the substitution of labor for capital. These consumers are unlikely to respond to marketing programs transplanted from developed markets. Instead, marketing programs need to be built from the ground up. But building marketing programs from the ground up questions fundamental marketing practices that are presumed to lie at the core of the success in traditional markets. The organizational tensions 
that arise as firms grapple with this dilemma can be wrenching. Firms will choose to live with the tension if they believe the opportunity presented by emerging markets to be worth the pain. One means of justifying the pain is to abandon the traditional practice of having country-focused strategies, such as a "China strategy" and an "India strategy," and to begin to consider the firm's "emerging market strategy." Framing the issue in this way places the focus on the commonalities across emerging markets and their real potential size. It, thus, enables an accurate assessment of the costs and benefits of localization.

The framework we have presented yields insights into the nature of the localization effort required. First, we show that the segments and segmentation schemes on which multinationals develop their brands for the affluent markets do not fit the realities of emerging markets. We also show that emerging markets, despite their diversity, are less segmentable due to the costs of segmentation, and consumers' unwillingness and inability to pay for the added costs of customized products. Consumers' income variability compounded by infrastructural variability calls for radical adaptation of marketing programs developed for the advanced economies. The substitution of labor for capital creates trade-offs that are unusual in developed markets. These inherent differences are sufficient to justify developing an alternative business model for emerging markets. Traditional business models that rely on innovation, fine segmentation, high margins, and finely tuned branding need to be rethought for emerging markets.

The pursuit of billion consumer markets requires that multinationals identify common factors that impact consumer behavior across emerging markets and design strategies for emerging markets as a group. For such a strategy to succeed, firms need to rapidly transfer learning across these markets. This requires a fundamental mindshift, from viewing emerging market subsidiaries as mere delivery mechanisms for programs developed elsewhere, to learning centers. Viewed in this light, the emerging market debate is naturally a debate about locally adaptive versus globally standardized 
strategies. However, the localization-globalization debate is much more pronounced in the context of emerging markets, where consumer behavior is so different, and the future stakes so high. 
Figure 1: The Impact of Emerging Market Characteristics on Marketing Programs

\begin{tabular}{|c|c|c|c|c|c|}
\hline & Segments & Product & Price & Distribution & Communication \\
\hline Low Incomes & $\begin{array}{l}\text { - Segments are } \\
\text { coarse and } \\
\text { diverse } \\
\text { because the } \\
\text { costs of } \\
\text { segmentation } \\
\text { are high. Mass } \\
\text { media are not } \\
\text { finely } \\
\text { segmented. }\end{array}$ & $\begin{array}{l}\text { Products need } \\
\text { to be } \\
\text { functional, } \\
\text { built to last, } \\
\text { and basic. } \\
\text { Rapid } \\
\text { obsolescence } \\
\text { is a mistake. }\end{array}$ & $\begin{array}{l}\text { Large } \\
\text { volumes, and } \\
\text { low margins } \\
\text { drive } \\
\text { profitability. } \\
\text { Consumers } \\
\text { gauge prices in } \\
\text { relation to a } \\
\text { local basket of } \\
\text { purchases. }\end{array}$ & $\begin{array}{l}\text { Retail } \\
\text { distribution is } \\
\text { highly } \\
\text { fragmented, } \\
\text { but } \\
\text { nevertheless, } \\
\text { powerful. }\end{array}$ & $\begin{array}{l}\text { Persuade } \\
\text { consumers to } \\
\text { consume more } \\
\text { and non- } \\
\text { consumers to } \\
\text { adopt the } \\
\text { product. }\end{array}$ \\
\hline Variability & $\begin{array}{l}\text { - Income } \\
\text { disparities and } \\
\text { income flow } \\
\text { variability lead } \\
\text { to co-existence } \\
\text { of very } \\
\text { different } \\
\text { market } \\
\text { segments. }\end{array}$ & $\begin{array}{l}\text { Quality } \\
\text { consistency is } \\
\text { at a premium, } \\
\text { and not easy to } \\
\text { achieve in a } \\
\text { variable } \\
\text { environment. } \\
\text { Design and } \\
\text { package for } \\
\text { infrastructural } \\
\text { and consumer } \\
\text { variability. }\end{array}$ & $\begin{array}{l}\text { Price } \\
\text { promotions } \\
\text { yield large } \\
\text { volume gains. } \\
\text { But it is } \\
\text { worthwhile to } \\
\text { launch second } \\
\text { tier brands } \\
\text { rather than } \\
\text { occasional } \\
\text { promotions. }\end{array}$ & $\begin{array}{l}\text { Urban and } \\
\text { rural retailers } \\
\text { look similar } \\
\text { but operate on } \\
\text { different } \\
\text { principles. It } \\
\text { pays to be first } \\
\text { in rural } \\
\text { markets. It } \\
\text { pays to be } \\
\text { differentiated } \\
\text { in urban } \\
\text { markets. }\end{array}$ & $\begin{array}{l}\text { Creating own } \\
\text { channels of } \\
\text { communication } \\
\text { where no mass } \\
\text { media exist to } \\
\text { cater to large } \\
\text { swathes of the } \\
\text { market. }\end{array}$ \\
\hline Cheap Labor & $\begin{array}{l}\text { Despite huge } \\
\text { differences in } \\
\text { consumers' } \\
\text { cost of time, } \\
\text { the market } \\
\text { cannot be } \\
\text { segmented on } \\
\text { this dimension } \\
\text { because time is } \\
\text { bought and } \\
\text { sold. }\end{array}$ & $\begin{array}{l}\text { Products can } \\
\text { be re- } \\
\text { engineered to } \\
\text { replace some } \\
\text { elements with } \\
\text { consumers' } \\
\text { labor. Makes } \\
\text { the product } \\
\text { more } \\
\text { affordable to } \\
\text { the mass } \\
\text { market. }\end{array}$ & $\begin{array}{l}\text { Consumers' } \\
\text { make versus } \\
\text { buy decisions } \\
\text { drive value } \\
\text { perceptions. } \\
\text { Competition } \\
\text { also comes in } \\
\text { shape of } \\
\text { home-made } \\
\text { products. }\end{array}$ & $\begin{array}{l}\text { People rather } \\
\text { than machines } \\
\text { provide a cost- } \\
\text { effective } \\
\text { means of } \\
\text { delivering } \\
\text { products to } \\
\text { consumers. }\end{array}$ & 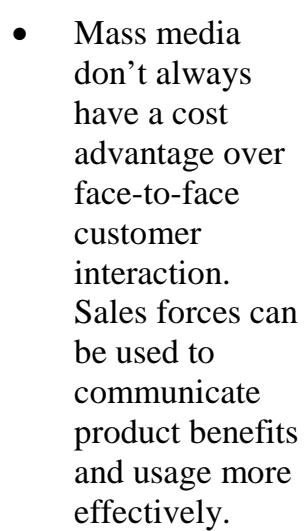 \\
\hline
\end{tabular}




\section{References}

${ }^{1}$ Prahalad C. K. and Kenneth Lieberthal (1998), "The End of Corporate Imperialism," Harvard Business Review, July-August, 68-79.

${ }^{2}$ Batra, Rajeev (1999), "Marketing Issues and Challenges in Transitional Economies," in Marketing Issues in Transitional Economies, Rajeev Batra, ed, Kluwer Academic Publishers, Boston: MA, 3-35.

${ }^{3}$ Arnold, David J. and John A. Quelch (1998), "New Strategies in Emerging Markets," Sloan Management Review, Fall, 7-20.

${ }^{4}$ Dawar, Niraj and Tony Frost (1999), "Competing with Giants: Survival Strategies for Local Companies in Emerging Markets," Harvard Business Review, March-April, 119-129.

${ }^{5}$ Chang Bum Choi and Paul Beamish (1998), "Samsung China: The Introduction of Color TV," Ivey Case Study, Ivey Publishing: London, Canada.

${ }^{6}$ Pan, Yigang and Xiaolian Li (1999), "Do Timing and Modes of Entry in China Matter to Market Share Position and Profitability?" in Marketing Issues in Transitional Economies, Rajeev Batra ed., Kluwer Acadamic Publishers, Boston: MA, 211-223.

${ }^{7}$ Neupert, K. E. (1997) “Dupont Teflon : China Brand Strategy,” Ivey Case Study, Ivey Publishing: London, Canada.

${ }^{8}$ Rangan, Kasturi V. (1997), "Citibank: Launching the Credit Card in Asia Pacific," HBS Case Study, Harvard Business School Publishing: Cambridge MA. 


\section{DAVIDSON INSTITUTE Working PAPER SERIES}

CURRENT AS OF 4/27/00

\begin{tabular}{|c|c|c|}
\hline Publication & Authors & Date of Paper \\
\hline $\begin{array}{l}\text { No. } 320 \text { Rethinking Marketing Programs for } \\
\text { Emerging Markets }\end{array}$ & Niraj Dawar and Amitava Chattopadhyay & June 2000 \\
\hline $\begin{array}{l}\text { No. } 319 \text { Public Finance and Low Equilibria in } \\
\text { Transition Economies; the Role of Institutions }\end{array}$ & Daniel Daianu and Radu Vranceanu & June 2000 \\
\hline $\begin{array}{l}\text { No. } 318 \text { Some Econometric Evidence on the } \\
\text { Effectiveness of Active Labour Market } \\
\text { Programmes in East Germany }\end{array}$ & Martin Eichler and Michael Lechner & June 2000 \\
\hline $\begin{array}{l}\text { No. } 317 \text { A Model of Russia's "Virtual } \\
\text { Economy" }\end{array}$ & R.E Ericson and B.W Ickes & May 2000 \\
\hline $\begin{array}{l}\text { No. } 316 \text { Financial Institutions, Financial } \\
\text { Contagion, and Financial Crises }\end{array}$ & Haizhou Huang and Chenggang Xu & March 2000 \\
\hline $\begin{array}{l}\text { No. } 315 \text { Privatization versus Regulation in } \\
\text { Developing Economies: The Case of West } \\
\text { African Banks }\end{array}$ & $\begin{array}{l}\text { Jean Paul Azam, Bruno Biais, and } \\
\text { Magueye Dia }\end{array}$ & February 2000 \\
\hline $\begin{array}{l}\text { No. } 314 \text { Is Life More Risky in the Open? } \\
\text { Household Risk-Coping and the Opening of } \\
\text { China's Labor Markets }\end{array}$ & John Giles & April 2000 \\
\hline $\begin{array}{l}\text { No. } 313 \text { Networks, Migration and Investment: } \\
\text { Insiders and Outsiders in Tirupur's } \\
\text { Production Cluster }\end{array}$ & Abhijit Banerjee and Kaivan Munshi & March 2000 \\
\hline $\begin{array}{l}\text { No. } 312 \text { Computational Analysis of the Impact } \\
\text { on India of the Uruguay Round and the } \\
\text { Forthcoming WTO Trade Negotiations }\end{array}$ & $\begin{array}{l}\text { Rajesh Chadha, Drusilla K. Brown, Alan } \\
\text { V. Deardorff and Robert M. Stern }\end{array}$ & March 2000 \\
\hline $\begin{array}{l}\text { No. } 311 \text { Subsidized Jobs for Unemployed } \\
\text { Workers in Slovakia }\end{array}$ & Jan. C. van Ours & May 2000 \\
\hline $\begin{array}{l}\text { No. } 310 \text { Determinants of Managerial Pay in } \\
\text { the Czech Republic }\end{array}$ & $\begin{array}{l}\text { Tor Eriksson, Jaromir Gottvald and Pavel } \\
\text { Mrazek }\end{array}$ & May 2000 \\
\hline $\begin{array}{l}\text { No. } 309 \text { The Great Human Capital } \\
\text { Reallocation: An Empirical Analysis of } \\
\text { Occupational Mobility in Transitional Russia }\end{array}$ & Klara Z. Sabirianova & May 2000 \\
\hline $\begin{array}{l}\text { No. } 308 \text { Economic Development, Legality, and } \\
\text { the Transplant Effect }\end{array}$ & $\begin{array}{l}\text { Daniel Berkowitz, Katharina Pistor, and } \\
\text { Jean-Francois Richard }\end{array}$ & February 2000 \\
\hline $\begin{array}{l}\text { No. } 307 \text { Community Participation, Teacher } \\
\text { Effort, and Educational Outcome: The Case of } \\
\text { El Salvador's EDUCO Program }\end{array}$ & Yasuyuki Sawada & November 1999 \\
\hline $\begin{array}{l}\text { No. } 306 \text { Gender Wage Gap and Segregation in } \\
\text { Late Transition }\end{array}$ & Stepan Jurajda & May 2000 \\
\hline $\begin{array}{l}\text { No. } 305 \text { The Gender Pay Gap in the } \\
\text { Transition from Communism: Some Empirical } \\
\text { Evidence }\end{array}$ & Andrew Newell and Barry Reilly & May 2000 \\
\hline $\begin{array}{l}\text { No. } 304 \text { Post-Unification Wage Growth in } \\
\text { East Germany }\end{array}$ & Jennifer Hunt & November 1998 \\
\hline $\begin{array}{l}\text { No. } 303 \text { How Does Privatization Affect } \\
\text { Workers? The Case of the Russian Mass } \\
\text { Privatization Program }\end{array}$ & Elizabeth Brainerd & May 2000 \\
\hline
\end{tabular}


William Davidson Institute Working Paper Number 320

\begin{tabular}{|c|c|c|}
\hline $\begin{array}{l}\text { No. } 302 \text { Liability for Past Environmental } \\
\text { Contamination and Privatization }\end{array}$ & Dietrich Earnhart & March 2000 \\
\hline No. 301 Varieties, Jobs and EU Enlargement & Tito Boeri and Joaquim Oliveira Martins & May 2000 \\
\hline No. 300 Employer Size Effects in Russia & Todd Idson & April 2000 \\
\hline $\begin{array}{l}\text { No. } 299 \text { Information Complements, } \\
\text { Substitutes, and Strategic Product Design }\end{array}$ & $\begin{array}{l}\text { Geoffrey G. Parker and Marshall W. Van } \\
\text { Alstyne }\end{array}$ & March 2000 \\
\hline $\begin{array}{l}\text { No. } 298 \text { Markets, Human Capital, and } \\
\text { Inequality: Evidence from Rural China }\end{array}$ & $\begin{array}{l}\text { Dwayne Benjamin, Loren Brandt, Paul } \\
\text { Glewwe, Li Guo, }\end{array}$ & May 2000 \\
\hline $\begin{array}{l}\text { No. } 297 \text { Corporate Governance in the Asian } \\
\text { Financial Crisis }\end{array}$ & $\begin{array}{l}\text { Simon Johnson, Peter Boone, Alasdair } \\
\text { Breach, and Eric Friedman }\end{array}$ & November 1999 \\
\hline $\begin{array}{l}\text { No. } 296 \text { Competition and Firm Performance: } \\
\text { Lessons from Russia }\end{array}$ & J. David Brown and John S. Earle & March 2000 \\
\hline $\begin{array}{l}\text { No. } 295 \text { Wage Determination in Russia: An } \\
\text { Econometric Investigation }\end{array}$ & Peter J. Luke and Mark E. Schaffer & March 2000 \\
\hline $\begin{array}{l}\text { No. 294: Can Banks Promote Enterprise } \\
\text { Restructuring?: Evidence From a Polish } \\
\text { Bank's Experience }\end{array}$ & John P. Bonin and Bozena Leven & March 2000 \\
\hline $\begin{array}{l}\text { No. 293: Why do Governments Sell Privatised } \\
\text { Companies Abroad? }\end{array}$ & $\begin{array}{l}\text { Bernardo Bortolotti, Marcella Fantini and } \\
\text { Carlo Scarpa }\end{array}$ & March 2000 \\
\hline $\begin{array}{l}\text { No. 292: Going Public in Poland: Case-by- } \\
\text { Case Privatizations, Mass Privatization and } \\
\text { Private Sector Initial Public Offerings }\end{array}$ & Wolfgang Aussenegg & December 1999 \\
\hline $\begin{array}{l}\text { No. 291: Institutional Technology and the } \\
\text { Chains of Trust: Capital Markets and } \\
\text { Privatization in Russia and the Czech } \\
\text { Republic }\end{array}$ & Bruce Kogut and Andrew Spicer & March 1999 \\
\hline $\begin{array}{l}\text { No. 290: Banking Crises and Bank Rescues: } \\
\text { The Effect of Reputation }\end{array}$ & Jenny Corbett and Janet Mitchell & January 2000 \\
\hline $\begin{array}{l}\text { No. 289: Do Active Labor Market Policies } \\
\text { Help Unemployed Workers to Find and Keep } \\
\text { Regular Jobs? }\end{array}$ & Jan C. van Ours & February 2000 \\
\hline $\begin{array}{l}\text { No. 288: Consumption Patterns of the New } \\
\text { Elite in Zimbabwe }\end{array}$ & Russell Belk & February 2000 \\
\hline $\begin{array}{l}\text { No. 287: Barter in Transition Economies: } \\
\text { Competing Explanations Confront Ukranian } \\
\text { Data }\end{array}$ & $\begin{array}{l}\text { Dalia Marin, Daniel Kaufmann and } \\
\text { Bogdan Gorochowskij }\end{array}$ & January 2000 \\
\hline $\begin{array}{l}\text { No. 286: The Quest for Pension Reform: } \\
\text { Poland's Security through Diversity }\end{array}$ & Marek Góra and Michael Rutkowski & January 2000 \\
\hline $\begin{array}{l}\text { No. 285: Disorganization and Financial } \\
\text { Collapse }\end{array}$ & Dalia Marin and Monika Schnitzer & October 1999 \\
\hline $\begin{array}{l}\text { No. 284: Coordinating Changes in M-form } \\
\text { and U-form Organizations }\end{array}$ & $\begin{array}{l}\text { Yingyi Qian, Gérard Roland and } \\
\text { Chenggang } X u\end{array}$ & May 1999 \\
\hline $\begin{array}{l}\text { No. 283: Why Russian Workers Do Not Move: } \\
\text { Attachment of Workers Through In-Kind } \\
\text { Payments }\end{array}$ & Guido Friebel and Sergei Guriev & October 1999 \\
\hline $\begin{array}{l}\text { No. 282: Lessons From Fiascos in Russian } \\
\text { Corporate Governance }\end{array}$ & Merritt B. Fox and Michael A. Heller & October 1999 \\
\hline $\begin{array}{l}\text { No. 281: Income Distribution and Price } \\
\text { Controls: Targeting a Social Safety Net } \\
\text { During Economic Transition }\end{array}$ & Michael Alexeev and James Leitzel & March 1999 \\
\hline $\begin{array}{l}\text { No. 280: Starting Positions, Reform Speed, } \\
\text { and Economic Outcomes in Transitioning } \\
\text { Economies }\end{array}$ & William Hallagan and Zhang Jun & January 2000 \\
\hline
\end{tabular}


William Davidson Institute Working Paper Number 320

\begin{tabular}{|c|c|c|}
\hline No. 279 : The Value of Prominent Directors & Yoshiro Miwa \& J. Mark Ramseyer & October 1999 \\
\hline No. 278: The System Paradigm & János Kornai & April 1998 \\
\hline $\begin{array}{l}\text { No. 277: The Developmental Consequences of } \\
\text { Foreign Direct Investment in the Transition } \\
\text { from Socialism to Capitalism: The } \\
\text { Performance of Foreign Owned Firms in } \\
\text { Hungary }\end{array}$ & Lawrence Peter King & September 1999 \\
\hline $\begin{array}{l}\text { No. 276: Stability and Disorder: An } \\
\text { Evolutionary Analysis of Russia's Virtual } \\
\text { Economy }\end{array}$ & Clifford Gaddy and Barry W. Ickes & November 1999 \\
\hline $\begin{array}{l}\text { No. 275: Limiting Government Predation } \\
\text { Through Anonymous Banking: A Theory with } \\
\text { Evidence from China. }\end{array}$ & $\begin{array}{l}\text { Chong-En Bai, David D. Li, Yingyi Qian } \\
\text { and Yijiang Wang }\end{array}$ & July 1999 \\
\hline *No. 274: Transition with Labour Supply & Tito Boeri & December 1999 \\
\hline $\begin{array}{l}\text { No. 273: Sectoral Restructuring and Labor } \\
\text { Mobility: A Comparative Look at the Czech } \\
\text { Republic }\end{array}$ & Vit Sorm and Katherine Terrell & November 1999 \\
\hline $\begin{array}{l}\text { *No. 272: Published in: Journal of } \\
\text { Comparative Economics "Returns to Human } \\
\text { Capital Under the Communist Wage Grid and } \\
\text { During the Transition to a Market Economy" } \\
\text { Vol. 27, pp. 33-60 1999. }\end{array}$ & $\begin{array}{l}\text { Daniel Munich, Jan Svejnar and Katherine } \\
\text { Terrell }\end{array}$ & October 1999 \\
\hline $\begin{array}{l}\text { No. 271: Barter in Russia: Liquidity Shortage } \\
\text { Versus Lack of Restructuring }\end{array}$ & Sophie Brana and Mathilde Maurel & June 1999 \\
\hline $\begin{array}{l}\text { No. 270: Tests for Efficient Financial } \\
\text { Intermediation with Application to China }\end{array}$ & Albert Park and Kaja Sehrt & March 1999 \\
\hline $\begin{array}{l}\text { No. 269a: Russian Privatization and } \\
\text { Corporate Governance: What Went Wrong? }\end{array}$ & $\begin{array}{l}\text { Bernard Black, Reinier Kraakman and } \\
\text { Anna Tarassova }\end{array}$ & May 2000 \\
\hline $\begin{array}{l}\text { No. 269: Russian Privatization and Corporate } \\
\text { Governance: What Went Wrong? }\end{array}$ & $\begin{array}{l}\text { Bernard Black, Reinier Kraakman and } \\
\text { Anna Tarassova }\end{array}$ & September 1999 \\
\hline $\begin{array}{l}\text { No. 268: Are Russians Really Ready for } \\
\text { Capitalism? }\end{array}$ & Susan Linz & September 1999 \\
\hline $\begin{array}{l}\text { No. 267: Do Stock Markets Promote } \\
\text { Economic Growth? }\end{array}$ & $\begin{array}{l}\text { Randall K. Filer, Jan Hanousek and Nauro } \\
\text { Campos }\end{array}$ & September 1999 \\
\hline $\begin{array}{l}\text { No. 266: Objectivity, Proximity and } \\
\text { Adaptability in Corporate Governance }\end{array}$ & Arnoud W.A Boot and Jonathan R. Macey & September 1999 \\
\hline $\begin{array}{l}\text { No. 265: When the Future is not What it Used } \\
\text { to Be: Lessons from the Western European } \\
\text { Experience to Forecasting Education and } \\
\text { Training in Transitional Economies }\end{array}$ & $\begin{array}{l}\text { Nauro F. Campos, Gerard Hughes, Stepan } \\
\text { Jurajda, and Daniel Munich }\end{array}$ & September 1999 \\
\hline $\begin{array}{l}\text { No. 264: The Institutional Foundation of } \\
\text { Foreign-Invested Enterprises (FIEs) in China }\end{array}$ & Yasheng Huang & September 1999 \\
\hline $\begin{array}{l}\text { No. 263: The Changing Corporate } \\
\text { Governance Paradigm: Implications for } \\
\text { Transition and Developing Countries }\end{array}$ & $\begin{array}{l}\text { Erik Berglof and Ernst-Ludwig von } \\
\text { Thadden }\end{array}$ & June 1999 \\
\hline No. 262: Law Enforcement and Transition & Gerard Roland and Thierry Verdier & May 1999 \\
\hline $\begin{array}{l}\text { No. 261: Soft Budget Constraints, Pecuniary } \\
\text { Externality, and the Dual Track System }\end{array}$ & Jiahua Che & June 2000 \\
\hline $\begin{array}{l}\text { No. 260: Missing Market in Labor Quality: } \\
\text { The Role of Quality Markets in Transiton }\end{array}$ & Gary H. Jefferson & July 1999 \\
\hline
\end{tabular}


William Davidson Institute Working Paper Number 320

\begin{tabular}{|c|c|c|}
\hline $\begin{array}{l}\text { No. 259: Do Corporate Global Environmental } \\
\text { Standards in Emerging Markets Create or } \\
\text { Destroy Market Value }\end{array}$ & $\begin{array}{l}\text { Glen Dowell, Stuart Hart and Bernard } \\
\text { Yeung }\end{array}$ & June 1999 \\
\hline $\begin{array}{l}\text { No. 258: Public Training and Outflows from } \\
\text { Unemployment }\end{array}$ & Patrick A. Puhani & June 1999 \\
\hline $\begin{array}{l}\text { No. 257: Ownership Versus Environment: } \\
\text { Why are Public Sector Firms Ineffecient? }\end{array}$ & Ann P. Bartel and Ann E. Harrison & June 1999 \\
\hline $\begin{array}{l}\text { No. 256: Taxation and Evasion in the } \\
\text { Presence of Exortion by Organized Crime }\end{array}$ & $\begin{array}{l}\text { Michael Alexeev, Eckhard Janeba and } \\
\text { Stefan Osborne }\end{array}$ & November 1999 \\
\hline $\begin{array}{l}\text { No. 255: Revisiting Hungary's Bankruptcy } \\
\text { Episode }\end{array}$ & John P. Bonin and Mark E. Schaffer & September 1999 \\
\hline $\begin{array}{l}\text { No. 254: FDI in Emerging Markets: A Home- } \\
\text { Country View }\end{array}$ & Marina v.N Whitman & June 1999 \\
\hline $\begin{array}{l}\text { No. 253: The Asian Financial Crisis: What } \\
\text { Happened, and What is to be Done }\end{array}$ & Jeffrey D. Sachs and Wing Thye Woo & January 1999 \\
\hline $\begin{array}{l}\text { No. 252: Organizational Law as Asset } \\
\text { Partitioning }\end{array}$ & Henry Hansmann and Reinier Kraakman & September 1999 \\
\hline $\begin{array}{l}\text { No. 251: Consumer Behavior Research in } \\
\text { Emerging Consumer Markets: the Case of the } \\
\text { Optimum Stimulation Level in South Africa }\end{array}$ & $\begin{array}{l}\text { Jan-Benedict E. M. Steenkamp and Steven } \\
\text { M. Burgess }\end{array}$ & September 1999 \\
\hline $\begin{array}{l}\text { No. 250: Property Rights Formation and the } \\
\text { Organization of Exchange and Production in } \\
\text { Rural China }\end{array}$ & $\begin{array}{l}\text { Matthew A. Turner, Loren Brandt, and } \\
\text { Scott Rozelle }\end{array}$ & July 1998 \\
\hline $\begin{array}{l}\text { No. 249: Impacts of the Indonesian Economic } \\
\text { Crisis: Price Changes and the Poor }\end{array}$ & $\begin{array}{l}\text { James Levinsohn, Steven Berry, and Jed } \\
\text { Friedman }\end{array}$ & June 1999 \\
\hline $\begin{array}{l}\text { No. 248: Internal Barriers in the Transition of } \\
\text { Enterprises from Central Plan to Market }\end{array}$ & Charalambos Vlachoutsicos & July 1999 \\
\hline $\begin{array}{l}\text { No. 247: Spillovers from Multinationals in } \\
\text { Developing Countries: the Mechanisms at } \\
\text { Work }\end{array}$ & Richard E. Caves & June 1999 \\
\hline $\begin{array}{l}\text { No. 246: Dynamism and Inertia on the } \\
\text { Russian Labour Market: A Model of } \\
\text { Segmentation }\end{array}$ & $\begin{array}{l}\text { Irena Grosfeld, Claudia Senik-Leygonie, } \\
\text { Thierry Verdier, Stanislav Kolenikov and } \\
\text { Elena Paltseva }\end{array}$ & May 1999 \\
\hline $\begin{array}{l}\text { No. 245: Lessons from Bank Privatization in } \\
\text { Central Europe }\end{array}$ & John Bonin and Paul Wachtel & May 1999 \\
\hline $\begin{array}{l}\text { No. 244: Nominal-Real Tradeoffs and the } \\
\text { Effects of Monetary Policy: the Romanian } \\
\text { Experience }\end{array}$ & Christian Popa & December 1998 \\
\hline $\begin{array}{l}\text { No. 243: Privatization, Political Risk and } \\
\text { Stock Market Development in Emerging } \\
\text { Economies }\end{array}$ & Enrico C. Perotti and Pieter van Oijen & March 1999 \\
\hline $\begin{array}{l}\text { No. 242: Investment Financing in Russian } \\
\text { Financial-Industrial Groups }\end{array}$ & Enrico C. Perotti and Stanislav Gelfer & October 1998 \\
\hline $\begin{array}{l}\text { No. 241: Can governments maintain hard } \\
\text { budget constraints? Bank lending and } \\
\text { financial isolation in Romania }\end{array}$ & $\begin{array}{l}\text { Octavian Carare, Constantijn Claessens, } \\
\text { Enrico C. Perotti }\end{array}$ & January 1999 \\
\hline $\begin{array}{l}\text { No. 240: Democratic Institutions and } \\
\text { Economic Reform: the Polish Case }\end{array}$ & $\begin{array}{l}\text { John E. Jackson, Jacek Klich, and } \\
\text { Krystyna Poznanska }\end{array}$ & April 1998 \\
\hline $\begin{array}{l}\text { No. 239: A Longitudinal Study of IJV } \\
\text { Performance in Eastern Europe }\end{array}$ & Keith D. Brouthers and Gary Bamossy & June 1999 \\
\hline
\end{tabular}




\begin{tabular}{|c|c|c|}
\hline $\begin{array}{l}\text { No. 238: Published in: Journal of Business } \\
\text { Venturing, "Firm Creation and Economic } \\
\text { Transitions" Vol. 14, Iss. 5,6 Sep/Nov 1999, } \\
\text { pp. 427-450. }\end{array}$ & $\begin{array}{l}\text { John E. Jackson, Jacek Klich, Krystyna } \\
\text { Poznanska }\end{array}$ & July 1998 \\
\hline $\begin{array}{l}\text { No. 237: Analysis of Entrepreneurial Attitudes } \\
\text { in Poland }\end{array}$ & $\begin{array}{l}\text { John E. Jackson and Aleksander S. } \\
\text { Marcinkowski }\end{array}$ & March 1997 \\
\hline $\begin{array}{l}\text { No. 236: Investment and Finance in De Novo } \\
\text { Private Firms: Empirical Results from the } \\
\text { Czech Republic, Hungary, and Poland }\end{array}$ & $\begin{array}{l}\text { Andrzej Bratkowski, Irena Grosfeld, Jacek } \\
\text { Rostowski }\end{array}$ & April 1999 \\
\hline $\begin{array}{l}\text { No. 235: Does a Soft Macroeconomic } \\
\text { Environment Induce Restructuring on the } \\
\text { Microeconomic Level during the Transition } \\
\text { Period? Evidence from Investment Behavior } \\
\text { of Czech Enterprises }\end{array}$ & Lubomír Lízal & June 1999 \\
\hline $\begin{array}{l}\text { No. 234: Banking Reform in China: Gradually } \\
\text { Strengthening Pillar or Fragile Reed? }\end{array}$ & John Bonin & June 1999 \\
\hline $\begin{array}{l}\text { No. 233: Theories of Soft Budget Constraints } \\
\text { and the Analysis of Banking Crises }\end{array}$ & Janet Mitchell & March 1999 \\
\hline $\begin{array}{l}\text { No. 232: Unemployment Risk, Precautionary } \\
\text { Savings, and Moonlighting in Russia }\end{array}$ & $\begin{array}{l}\text { Alessandra Guariglia and Byung-Yeon } \\
\text { Kim }\end{array}$ & June 1999 \\
\hline $\begin{array}{l}\text { No. 231: Investing in Turbulent Times: The } \\
\text { Investment Behavior of Polish Firms in the } \\
\text { Transition }\end{array}$ & $\begin{array}{l}\text { Josef C. Brada, Arthur E. King, and Chia- } \\
\text { Ying Ma }\end{array}$ & April 1999 \\
\hline $\begin{array}{l}\text { No. 230: The End of Moderate Inflation in } \\
\text { Three Transition Economies? }\end{array}$ & Josef C. Brada and Ali M. Kutan & April 1999 \\
\hline $\begin{array}{l}\text { No. 229: Back to the Future: The Growth } \\
\text { Prospects of Transition Economies } \\
\text { Reconsidered }\end{array}$ & Nauro F. Campos & April 1999 \\
\hline $\begin{array}{l}\text { No. 228: The Enterprise Isolation Program in } \\
\text { Russia }\end{array}$ & Simeon Djankov & April 1999 \\
\hline $\begin{array}{l}\text { No. 227: Published in: Journal of } \\
\text { Comparative Economics, “Ownership } \\
\text { Concentration and Corporate Performance in } \\
\text { the Czech Republic” 27(3), September 1999, } \\
\text { pp. 498-513. }\end{array}$ & Stijn Claessens and Simeon Djankov & April 1999 \\
\hline $\begin{array}{l}\text { No. 226: Unemployment Benefit Entitlement } \\
\text { and Training Effects in Poland during } \\
\text { Transition }\end{array}$ & Patrick A. Puhani & March 1999 \\
\hline $\begin{array}{l}\text { No. 225: Transition at Whirlpool-Tatramat: } \\
\text { Case Studies }\end{array}$ & Hans Brechbuhl and Sonia Ferencikova & March 1999 \\
\hline $\begin{array}{l}\text { No. 224: Measuring Progress in Transition } \\
\text { and Towards EU Accession: A Comparison of } \\
\text { Manufacturing Firms in Poland, Romania, } \\
\text { and Spain }\end{array}$ & $\begin{array}{l}\text { Wendy Carlin, Saul Estrin, and Mark } \\
\text { Schaffer }\end{array}$ & March 1999 \\
\hline $\begin{array}{l}\text { No. 223: Product Market Competition in } \\
\text { Transition Economies: Increasing Varieties } \\
\text { and Consumer Loyalty }\end{array}$ & Mitsutoshi M. Adachi & March 1999 \\
\hline $\begin{array}{l}\text { No. 222: Opaque Markets and Rapid Growth: } \\
\text { the Superiority of Bank-Centered Financial } \\
\text { Systems for Developing Nations }\end{array}$ & Rodney Wallace & July 1999 \\
\hline $\begin{array}{l}\text { No. 221: Technology Spillovers through } \\
\text { Foreign Direct Investment }\end{array}$ & Yuko Kinoshita & January 1999 \\
\hline
\end{tabular}


William Davidson Institute Working Paper Number 320

\begin{tabular}{|c|c|c|}
\hline $\begin{array}{l}\text { No. 220: Managerial, Expertise and Team } \\
\text { Centered Forms of Organizing: A Cross- } \\
\text { Cultural Exploration of Independence in } \\
\text { Engineering Work }\end{array}$ & Leslie Perlow & January 1999 \\
\hline $\begin{array}{l}\text { No. 219: Household Structure and Labor } \\
\text { Demand in Agriculture: Testing for } \\
\text { Separability in Rural China }\end{array}$ & Audra J. Bowlus and Terry Sicular & January 1999 \\
\hline $\begin{array}{l}\text { No. 218: Competing Strategies of FDI and } \\
\text { Technology Transfer to China: American and } \\
\text { Japanese Firms }\end{array}$ & W. Mark Fruin and Penelope Prime & January 1999 \\
\hline $\begin{array}{l}\text { No. } 217 \text { Published in: Journal of } \\
\text { Comparative Economics, "Returns to } \\
\text { Mobility in the Transition to a Market } \\
\text { Economy" Vol. 27, No. 1, March 1999, pp. 4- }\end{array}$ & Tito Boeri and Christopher J. Flinn & January 1999 \\
\hline $\begin{array}{l}\text { No. } 216 \text { Published in: Journal of } \\
\text { Comparative Economics, "Labor Market } \\
\text { Policies and Unemployment in the Czech } \\
\text { Republic." Vol. 27, No. 1, March 1999, pp. } \\
\text { 33-60. }\end{array}$ & Katherine Terrell and Vit Sorm & November 1998 \\
\hline $\begin{array}{l}\text { No. } 215 \text { Published in: Journal of } \\
\text { Comparative Economics, “Active Labor } \\
\text { Market Policies in Poland: Human Capital } \\
\text { Enhancement, Stigmatization or Benefit } \\
\text { Churning?" Vol. 27, No. 1, March 1999, pp. } \\
61-\end{array}$ & $\begin{array}{l}\text { Jochen Kluve, Hartmut Lehmann, and } \\
\text { Christoph M. Schmidt }\end{array}$ & December 1998 \\
\hline $\begin{array}{l}\text { No. } 214 \text { Published in: Journal of } \\
\text { Comparative Economics, "Does the Slovenian } \\
\text { Public Work Program Increase Participants' } \\
\text { Chances to Find a Job?" Vol. 27, No.1, } \\
\text { March 1999, pp. 113- }\end{array}$ & Milan Vodopivec & December 1998 \\
\hline $\begin{array}{l}\text { No. } 213 \text { Published in: Journal of } \\
\text { Comparative Economics, "Effects of Active } \\
\text { Labor Market Programs on the Transition } \\
\text { Rate from Unemployment into Regular Jobs in } \\
\text { the Slovak Republic.” Vol. 27, No. 1, March } \\
\text { 1999, pp. 90- }\end{array}$ & Martina Lubyova and Jan C. van Ours & December 1998 \\
\hline $\begin{array}{l}\text { No. 212: The Marketing System in Bulgarian } \\
\text { Livestock Production - The Present State and } \\
\text { Evolutionary Processes During the Period of } \\
\text { Economic Transition }\end{array}$ & Yordan Staykov, Team Leader & October 1998 \\
\hline $\begin{array}{l}\text { No. 211: Bankruptcy Experience in Hungary } \\
\text { and the Czech Republic }\end{array}$ & Janet Mitchell & October 1998 \\
\hline $\begin{array}{l}\text { No 210: Values, Optimum Stimulation Levels } \\
\text { and Brand Loyalty: New Scales in New } \\
\text { Populations }\end{array}$ & Steven M. Burgess and Mari Harris & September 1998 \\
\hline $\begin{array}{l}\text { No. 209: Inherited Wealth, Corporate Control } \\
\text { and Economic Growth }\end{array}$ & $\begin{array}{l}\text { Randall K. Morck, David A. Stangeland, } \\
\text { and Bernard Yeung }\end{array}$ & September 1998 \\
\hline $\begin{array}{l}\text { No. 208: A Cultural Analysis of Homosocial } \\
\text { Reproduction and Contesting Claims to } \\
\text { Competence in Transitional Firms }\end{array}$ & Michael D. Kennedy & July 1998 \\
\hline
\end{tabular}


William Davidson Institute Working Paper Number 320

\begin{tabular}{|c|c|c|}
\hline $\begin{array}{l}\text { No. 207: From Survival to Success: The } \\
\text { Journey of Corporate Transformation at } \\
\text { Haier. Forthcoming in Teaching the } \\
\text { Dinosaurs to Dance: Organizational Change } \\
\text { in Transition Economies ed. Daniel Denison. } \\
\text { No. 206: Why Do People Work If They Are } \\
\text { Not Paid? An Example from Eastern Europe. } \\
\text { Forthcoming in Teaching the Dinosaurs to } \\
\text { Dance: Organizational Change in Transition } \\
\text { Economies ed. Daniel Denison. }\end{array}$ & $\begin{array}{l}\text { Arthur Yeung and Kenneth DeWoskin } \\
\text { Irina L. Zinovieva }\end{array}$ & $\begin{array}{l}\text { July } 1998 \\
\text { May } 1998\end{array}$ \\
\hline $\begin{array}{l}\text { No. 205: Firm Ownership and Work } \\
\text { Motivation in Bulgaria and Hungary: An } \\
\text { Empirical Study of the Transition in the Mid- } \\
\text { 1990s. Forthcoming in Teaching the } \\
\text { Dinosaurs to Dance: Organizational Change } \\
\text { in Transition Economies ed. Daniel Denison. }\end{array}$ & $\begin{array}{l}\text { Robert A. Roe, Irina L. Zinovieva, } \\
\text { Elizabeth Dienes, and Laurens A. ten Horn }\end{array}$ & May 1998 \\
\hline $\begin{array}{l}\text { No. 204: Human Resource Management in the } \\
\text { Restructuring of Chinese Joint Ventures. } \\
\text { Forthcoming in Teaching the Dinosaurs to } \\
\text { Dance: Organizational Change in Transition } \\
\text { Economies ed. Daniel Denison. }\end{array}$ & Nandani Lynton & April 1998 \\
\hline $\begin{array}{l}\text { No. 203: Emergent Compensation Strategies } \\
\text { in Post-Socialist Poland: Understanding the } \\
\text { Cognitive Underpinnings of Management } \\
\text { Practices in a Transition Economy. } \\
\text { Forthcoming in Teaching the Dinosaurs to } \\
\text { Dance: Organizational Change in Transition } \\
\text { Economies ed. Daniel Denison. }\end{array}$ & Marc Weinstein & March 1998 \\
\hline $\begin{array}{l}\text { No. 202: Corporate Transformation and } \\
\text { Organizational Learning: The People's } \\
\text { Republic of China. Forthcoming in Teaching } \\
\text { the Dinosaurs to Dance: Organizational } \\
\text { Change in Transition Economies ed. Daniel } \\
\text { Denison. }\end{array}$ & Meinolf Dierkes and Zhang Xinhua & March 1998 \\
\hline $\begin{array}{l}\text { No. 201: Foreign Direct Investment as a } \\
\text { Factor of Change: The Case of Slovakia. } \\
\text { Forthcoming in Teaching the Dinosaurs to } \\
\text { Dance: Organizational Change in Transition } \\
\text { Economies ed. Daniel Denison. }\end{array}$ & Sonia Ferencikova & February 1998 \\
\hline $\begin{array}{l}\text { No. 200: Radical versus Incremental Change: } \\
\text { The Role of Capabilities, Competition, and } \\
\text { Leaders. Forthcoming in Teaching the } \\
\text { Dinosaurs to Dance: Organizational Change } \\
\text { in Transition Economies ed. Daniel Denison. }\end{array}$ & Karen L. Newman & February 1998 \\
\hline $\begin{array}{l}\text { No. 199: The Emergence of Market Practices } \\
\text { in China's Economic Transition: Price Setting } \\
\text { Practices in Shanghai's Industrial Firms. } \\
\text { Forthcoming in Teaching the Dinosaurs to } \\
\text { Dance: Organizational Change in Transition } \\
\text { Economies ed. Daniel Denison. }\end{array}$ & Douglas Guthrie & February 1998 \\
\hline
\end{tabular}




\begin{tabular}{|c|c|c|}
\hline $\begin{array}{l}\text { No. 198: The Application of Change } \\
\text { Management Methods at Business } \\
\text { Organizations Operating in Hungary: } \\
\text { Challenges in the Business and Cultural } \\
\text { Environment and First Practical Experiences. } \\
\text { Forthcoming in Teaching the Dinosaurs to } \\
\text { Dance: Organizational Change in Transition } \\
\text { Economies ed. Daniel Denison. }\end{array}$ & Dr. János Fehér & January 1998 \\
\hline $\begin{array}{l}\text { No. 197: Organizational Changes in Russian } \\
\text { Industrial Enterprises: Mutation of Decision- } \\
\text { Making Structures and Transformations of } \\
\text { Ownership. Forthcoming in Teaching the } \\
\text { Dinosaurs to Dance: Organizational Change } \\
\text { in Transition Economies ed. Daniel Denison. }\end{array}$ & Igor B. Gurkov & January 1998 \\
\hline $\begin{array}{l}\text { No. 196: Understanding and Managing } \\
\text { Challenges to the Romanian Companies } \\
\text { during Transition. Forthcoming in Teaching } \\
\text { the Dinosaurs to Dance: Organizational } \\
\text { Change in Transition Economies ed. Daniel } \\
\text { Denison. }\end{array}$ & Dan Candea and Rodica M. Candea & January 1998 \\
\hline $\begin{array}{l}\text { No. 195: Insider Lending and Economic } \\
\text { Transition: The Structure, Function, and } \\
\text { Performance Impact of Finance Companies in } \\
\text { Chinese Business Groups. Forthcoming in } \\
\text { Teaching the Dinosaurs to Dance: } \\
\text { Organizational Change in Transition } \\
\text { Economies ed. Daniel Denison. }\end{array}$ & Lisa A. Keister & December 1997 \\
\hline $\begin{array}{l}\text { No. 194: Japanese Investment in Transitional } \\
\text { Economies: Characteristics and Performance. } \\
\text { Forthcoming in Teaching the Dinosaurs to } \\
\text { Dance: Organizational Change in Transition } \\
\text { Economies ed. Daniel Denison. }\end{array}$ & Paul W. Beamish and Andrew Delios & November 1997 \\
\hline $\begin{array}{l}\text { No. 193: Building Successful Companies in } \\
\text { Transition Economies. Forthcoming in } \\
\text { Teaching the Dinosaurs to Dance: } \\
\text { Organizational Change in Transition } \\
\text { Economies ed. Daniel Denison. }\end{array}$ & Dr. Ivan Perlaki & January 1998 \\
\hline $\begin{array}{l}\text { No. 192: Russian Communitariansim: An } \\
\text { Invisible Fist in the Transformation Process of } \\
\text { Russia. Forthcoming in Teaching the } \\
\text { Dinosaurs to Dance: Organizational Change } \\
\text { in Transition Economies ed. Daniel Denison. }\end{array}$ & Charalambos Vlachoutsicos & July 1998 \\
\hline No. 191: Teaching the Dinosaurs to Dance & Michal Cakrt & September 1997 \\
\hline $\begin{array}{l}\text { No. 190: Strategic Restructuring: Making } \\
\text { Capitalism in Post-Communist Eastern } \\
\text { Europe. Forthcoming in Teaching the } \\
\text { Dinosaurs to Dance: Organizational Change } \\
\text { in Transition Economies ed. Daniel Denison. }\end{array}$ & Lawrence P. King & September 1997 \\
\hline $\begin{array}{l}\text { No. 189: Published in: Regional Science and } \\
\text { Urban Economics, “Russia's Internal } \\
\text { Border”, } 29 \text { (5), September 1999. }\end{array}$ & Daniel Berkowitz and David N. DeJong & July 1998 \\
\hline $\begin{array}{l}\text { No. 187: Corporate Structure and } \\
\text { Performance in Hungary }\end{array}$ & László Halpern and Gábor Kórsöi & July 1998 \\
\hline
\end{tabular}


William Davidson Institute Working Paper Number 320

\begin{tabular}{|c|c|c|}
\hline $\begin{array}{l}\text { No. 186: Performance of Czech Companies by } \\
\text { Ownership Structure }\end{array}$ & Andrew Weiss and Georgiy Nikitin & June 1998 \\
\hline $\begin{array}{l}\text { No. 185: Firm Performance in Bulgaria and } \\
\text { Estonia: The effects of competitive pressure, } \\
\text { financial pressure and disorganisation }\end{array}$ & Jozef Konings & July 1998 \\
\hline $\begin{array}{l}\text { No. 184: Investment and Wages during the } \\
\text { Transition: Evidence from Slovene Firms }\end{array}$ & Janez Prasnikar and Jan Svejnar & July 1998 \\
\hline $\begin{array}{l}\text { No. 183: Investment Portfolio under Soft } \\
\text { Budget: Implications for Growth, Volatility } \\
\text { and Savings }\end{array}$ & Chongen Bai and Yijiang Wang & \\
\hline $\begin{array}{l}\text { No. 181: Delegation and Delay in Bank } \\
\text { Privatization }\end{array}$ & Loránd Ambrus-Lakatos and Ulrich Hege & July 1998 \\
\hline $\begin{array}{l}\text { No. 180: Financing Mechanisms and } R \& D \\
\text { Investment }\end{array}$ & Haizhou Huang and Chenggang Xu & July 1998 \\
\hline $\begin{array}{l}\text { No. 179: Organizational Culture and } \\
\text { Effectiveness: The Case of Foreign Firms in } \\
\text { Russia }\end{array}$ & Carl F. Fey and Daniel R. Denison & January 1999 \\
\hline $\begin{array}{l}\text { No. 178: Output and Unemployment } \\
\text { Dynamics in Transition }\end{array}$ & Vivek H. Dehejia and Douglas W. Dwyer & January 1998 \\
\hline $\begin{array}{l}\text { No. 177: Published in: Economics of } \\
\text { Transition,, “Bureaucracies in the Russian } \\
\text { Voucher Privatization” Vol. } 8, \text { No. } 1,2000 \text {, } \\
\text { pp. } 37-57 .\end{array}$ & Guido Friebel & June 1998 \\
\hline $\begin{array}{l}\text { No. 176: Chronic Moderate Inflation in } \\
\text { Transition: The Tale of Hungary }\end{array}$ & János Vincze & June 1998 \\
\hline $\begin{array}{l}\text { No. 175: Privatisation and Market Structure } \\
\text { in a Transition Economy }\end{array}$ & John Bennett and James Maw & June 1998 \\
\hline $\begin{array}{l}\text { No. 174: Ownership and Managerial } \\
\text { Competition: Employee, Customer, or Outside } \\
\text { Ownership }\end{array}$ & Patrick Bolton and Chenggang $\mathrm{Xu}$ & June 1998 \\
\hline $\begin{array}{l}\text { No. 173: Intragovernment Procurement of } \\
\text { Local Public Good: A Theory of } \\
\text { Decentralization in Nondemocratic } \\
\text { Government }\end{array}$ & Chong-en Bai, Yu Pan and Yijiang Wang & June 1998 \\
\hline $\begin{array}{l}\text { No. 172: Political Instability and Growth in } \\
\text { Proprietary Economies }\end{array}$ & Jody Overland and Michael Spagat & August 1998 \\
\hline $\begin{array}{l}\text { No. 171: Published in Post-Communist } \\
\text { Economies, "Framework Issues in the } \\
\text { Privatization Strategies of the Czech Republic, } \\
\text { Hungary, and Poland" Vol. 11, no. 1 March } \\
\text { 1999. }\end{array}$ & Morris Bornstein & June 1998 \\
\hline $\begin{array}{l}\text { No. 170: Published in: European Journal of } \\
\text { Political Economy "Privatization, Ownership } \\
\text { Structure and Transparency: How to Measure } \\
\text { a Real Involvement of the State" 15(4), } \\
\text { November 1999, pp. 605-18. }\end{array}$ & Frantisek Turnovec & May 1998 \\
\hline $\begin{array}{l}\text { No. } 169 \text { Published in: American Economic } \\
\text { Review, "Unemployment and the Social Safety } \\
\text { Net during Transitions to a Market Economy: } \\
\text { Evidence from Czech and Slovak Men." Vol. } \\
\text { 88, No. 5, Dec. 1998, pp. 1117-1142. }\end{array}$ & $\begin{array}{l}\text { John C. Ham, Jan Svejnar, and Katherine } \\
\text { Terrell }\end{array}$ & December 1998 \\
\hline $\begin{array}{l}\text { No. 167: Voucher Privatization with } \\
\text { Investment Funds: An Institutional Analysis }\end{array}$ & David Ellerman & March 1998 \\
\hline
\end{tabular}


William Davidson Institute Working Paper Number 320

\begin{tabular}{|c|c|c|}
\hline $\begin{array}{l}\text { No. 166: Published in: Marketing Issues in } \\
\text { Transitional Economies, "Value Priorities } \\
\text { and Consumer Behavior in a Transitional } \\
\text { Economy: The Case of South Africa” ed. } \\
\text { Rajeev Batra. }\end{array}$ & $\begin{array}{l}\text { Steven M. Burgess and Jan-Benedict E.M. } \\
\text { Steenkamp }\end{array}$ & August 1998 \\
\hline $\begin{array}{l}\text { No. 164: Finance and Investment in } \\
\text { Transition: Czech Enterprises, 1993-1994 }\end{array}$ & Ronald Anderson and Chantal Kegels & September 1997 \\
\hline $\begin{array}{l}\text { No. 163: European Union Trade and } \\
\text { Investment Flows U-Shaping Industrial } \\
\text { Output in Central and Eastern Europe: } \\
\text { Theory and Evidence }\end{array}$ & Alexander Repkine and Patrick P. Walsh & April 1998 \\
\hline $\begin{array}{l}\text { No. 162: Skill Acquisition and Private Firm } \\
\text { Creation in Transition Economies }\end{array}$ & Zuzana Brixiova and Wenli Li & October 1999 \\
\hline No. 161: Corruption in Transition & Susanto Basu and David D. Li & May 1998 \\
\hline $\begin{array}{l}\text { No. 160a: Tenures that Shook the World: } \\
\text { Worker Turnover in Russia, Poland and } \\
\text { Britain }\end{array}$ & $\begin{array}{l}\text { Hartmut Lehmann and Jonathan } \\
\text { Wadsworth }\end{array}$ & November 1999 \\
\hline $\begin{array}{l}\text { No. 160: Tenures that Shook the World: } \\
\text { Worker Turnover in the Russian Federation } \\
\text { and Poland }\end{array}$ & $\begin{array}{l}\text { Hartmut Lehmann and Jonathan } \\
\text { Wadsworth }\end{array}$ & June 1998 \\
\hline $\begin{array}{l}\text { No. 159: Does Market Structure Matter? New } \\
\text { Evidence from Russia }\end{array}$ & Annette N. Brown and J. David Brown & June 1998 \\
\hline $\begin{array}{l}\text { No. 158: Structural Adjustment and Regional } \\
\text { Long Term Unemployment in Poland }\end{array}$ & Hartmut Lehmann and Patrick P. Walsh & June 1997 \\
\hline $\begin{array}{l}\text { No. 157: Baby Boom or Bust? Changing } \\
\text { Fertility in Post-Communist Czech Republic } \\
\text { and Slovakia }\end{array}$ & Robert S. Chase & April 1998 \\
\hline $\begin{array}{l}\text { No. } 156 \text { Published in: Leadership and } \\
\text { Organization Development Journal, } \\
\text { “Leading Radical Change in Transition } \\
\text { Economies.” Vol. 19, No. 6, 1998, pp. 309- } \\
324 .\end{array}$ & Karen L. Newman & June 1998 \\
\hline $\begin{array}{l}\text { No. } 155 \text { Published in: Oxford Review of } \\
\text { Economic Policy, "From Theory into } \\
\text { Practice? Restructuring and Dynamism in } \\
\text { Transition Economies.”Vol. 13, No. 2, } \\
\text { Summer 1997, pp. 77-105. }\end{array}$ & Wendy Carlin and Michael Landesmann & June 1997 \\
\hline $\begin{array}{l}\text { No. 154: The Model and the Reality: } \\
\text { Assessment of Vietnamese SOE Reform- } \\
\text { Implementation at the Firm Level }\end{array}$ & $\begin{array}{l}\text { Edmund Malesky, Vu Thanh Hung, Vu Thi } \\
\text { Dieu Anh, and Nancy K. Napier }\end{array}$ & July 1998 \\
\hline $\begin{array}{l}\text { No. } 153 \text { Published in: Journal of } \\
\text { Comparative Economics, “Causes of the Soft } \\
\text { Budget Constraint: Evidence on Three } \\
\text { Explanations.” Vol. 26, No. 1, March 1998, } \\
\text { pp. 104-116. }\end{array}$ & David D. Li and Minsong Liang & March 1998 \\
\hline $\begin{array}{l}\text { No. } 152 \text { Published in: Comparative Economic } \\
\text { Studies, “Enterprise Restructuring in Russia's } \\
\text { Transition Economy: Formal and Informal } \\
\text { Mechanisms.” Vol. 40, No. 2, Summer 1998, } \\
\text { pp. 5-52. }\end{array}$ & Susan J. Linz and Gary Krueger & April 1998 \\
\hline $\begin{array}{l}\text { No. 151: Labor Productivity in Transition: A } \\
\text { Regional Analysis of Russian Industry }\end{array}$ & Susan J. Linz. & May 1998 \\
\hline
\end{tabular}




\begin{tabular}{|c|c|c|}
\hline $\begin{array}{l}\text { No. 150: Tax Avoidance and the Allocation of } \\
\text { Credit. Forthcoming in Financial Systems in } \\
\text { Transition: The Design of Financial Systems } \\
\text { in Central Europe eds. Anna Meyendorff and } \\
\text { Anjan Thakor. }\end{array}$ & Anna Meyendorff & June 1998 \\
\hline $\begin{array}{l}\text { No. 149: Commitment, Versatility and } \\
\text { Balance: Determinants of Work Time } \\
\text { Standards and Norms in a Multi-Country } \\
\text { Study of Software Engineers }\end{array}$ & Leslie Perlow and Ron Fortgang & April 1998 \\
\hline $\begin{array}{l}\text { No. 148: Changes in Poland's Transfer } \\
\text { Payments in the 1990s: the Fate of } \\
\text { Pensioners }\end{array}$ & Bozena Leven & June 1998 \\
\hline $\begin{array}{l}\text { No. 147: Environmental Protection and } \\
\text { Economic Development: The Case of the } \\
\text { Huaihe River Basin Cleanup Plan }\end{array}$ & $\begin{array}{l}\text { Robert Letovsky, Reze Ramazani, and } \\
\text { Debra Murphy }\end{array}$ & June 1998 \\
\hline $\begin{array}{l}\text { No. 146: Chief Executive Compensation } \\
\text { During Early Transition: Further Evidence } \\
\text { from Bulgaria }\end{array}$ & $\begin{array}{l}\text { Derek C. Jones, Takao Kato, and Jeffrey } \\
\text { Miller }\end{array}$ & June 1998 \\
\hline $\begin{array}{l}\text { No. } 145 \text { Published in: Economics of } \\
\text { Transition, “Women's Unemployment During } \\
\text { the Transition: Evidence from Czech and } \\
\text { Slovak Micro Data," Vol. 7, No. 1, May 1999, } \\
\text { pp. 47-78. }\end{array}$ & $\begin{array}{l}\text { John Ham, Jan Svejnar, and Katherine } \\
\text { Terrell }\end{array}$ & May 1998 \\
\hline No. 144: Investment and Wages in Slovenia & Janez Prasnikar & May 1998 \\
\hline $\begin{array}{l}\text { No. } 143 \text { Published in: Review of Financial } \\
\text { Studies, “Optimal Bankruptcy Laws Across } \\
\text { Different Economic Systems,” 12(2), Summer } \\
\text { 1999, pgs. 347-77. }\end{array}$ & Elazar Berkovitch and Ronen Israel & March 1998 \\
\hline $\begin{array}{l}\text { No. 142: Industrial Policy and Poverty in } \\
\text { Transition Economies: Two Steps Forward or } \\
\text { One Step Back? }\end{array}$ & Susan J. Linz & March 1998 \\
\hline $\begin{array}{l}\text { No. 141: Collective Ownership and } \\
\text { Privatization of China's Village Enterprises }\end{array}$ & Suwen Pan and Albert Park & April 1998 \\
\hline $\begin{array}{l}\text { No. 140: A Comparative Look at Labor } \\
\text { Mobility in the Czech Republic: Where have } \\
\text { all the Workers Gone? }\end{array}$ & Vit Sorm and Katherine Terrell & April 1999 \\
\hline $\begin{array}{l}\text { No. 139: The Failure of the Government-Led } \\
\text { Program of Corporate Reorganization in } \\
\text { Romania }\end{array}$ & Simeon Djankov and Kosali Ilayperuma & September 1997 \\
\hline $\begin{array}{l}\text { No. 138: Ownership and Employment in } \\
\text { Russian Industry: 1992-1995 }\end{array}$ & Susan J. Linz & March 1998 \\
\hline $\begin{array}{l}\text { No. } 137 \text { Published in: Journal of Political } \\
\text { Economy, “Reform Without Losers: An } \\
\text { Interpretation of China's Dual-Track } \\
\text { Approach to Transition," Feb. 2000; Vol. 108, } \\
\text { Iss.1; pg. } 120\end{array}$ & $\begin{array}{l}\text { Lawrence J. Lau, Yingyi Qian, and Gerard } \\
\text { Roland }\end{array}$ & November 1997 \\
\hline $\begin{array}{l}\text { No. } 136 \text { Published in: European Economic } \\
\text { Review, "The Political Economy of Mass } \\
\text { Privatization and the Risk of Expropriation," } \\
44(2), \text { February 2000, pgs. 393-421 }\end{array}$ & Klaus M. Schmidt & March 1998 \\
\hline $\begin{array}{l}\text { No. 135: Radical Organizational Change: The } \\
\text { Role of Starting Conditions, Competition, and } \\
\text { Leaders }\end{array}$ & Karen L. Newman & January 1998 \\
\hline
\end{tabular}


William Davidson Institute Working Paper Number 320

\begin{tabular}{|c|c|c|}
\hline $\begin{array}{l}\text { No. 134: To Restructure or Not to } \\
\text { Restructure: Informal Activities and } \\
\text { Enterprise Behavior in Transition } \\
\text { No. 133: Management 101: Behavior of Firms } \\
\text { in Transition Economies }\end{array}$ & $\begin{array}{l}\text { Clifford Gaddy and Barry W. Ickes } \\
\text { Josef C. Brada }\end{array}$ & $\begin{array}{l}\text { May } 1998 \\
\text { March } 1998\end{array}$ \\
\hline $\begin{array}{l}\text { No. } 132 \text { Published in: Quarterly Journal of } \\
\text { Economics, "Interfirm Relationships and } \\
\text { Informal Credit in Vietnam," 114(4), Nov. } \\
\text { 1999, pgs. 1285-1320 }\end{array}$ & John McMillan and Christopher Woodruff & February 1998 \\
\hline $\begin{array}{l}\text { No. } 131 \text { Published in: Comparative Economic } \\
\text { Studies, “Will Restructuring Hungarian } \\
\text { Companies Innovate? An Investigation Based } \\
\text { on Joseph Berliner's Analysis of Innovation in } \\
\text { Soviet Industry.” Vol. 40, No. 2, Summer } \\
\text { 1998, pp. 53-74. }\end{array}$ & John B. Bonin and Istvan Abel & March 1998 \\
\hline $\begin{array}{l}\text { No. 130: Published in The American } \\
\text { Economic Review, "Changing Incentives of } \\
\text { the Chinese Bureaucracy.” May, } 1998 .\end{array}$ & David D. Li & January 1998 \\
\hline $\begin{array}{l}\text { No. 129: Restructuring Investment in } \\
\text { Transition: A Model of the Enterprise } \\
\text { Decision }\end{array}$ & Richard E. Ericson & January 1998 \\
\hline $\begin{array}{l}\text { No. } 128 \text { Published in: Comparative Economic } \\
\text { Studies, “Job Rights in Russian Firms: } \\
\text { Endangered or Extinct Institutions?” Vol. 40, } \\
\text { No. 4, Winter 1998, pp. 1-32. }\end{array}$ & Susan J. Linz & January 1998 \\
\hline $\begin{array}{l}\text { No. 127: Accounting for Growth in Post- } \\
\text { Soviet Russia }\end{array}$ & Daniel Berkowitz and David N. DeJong & January 1998 \\
\hline $\begin{array}{l}\text { No. } 126 \text { Published in: Economics of } \\
\text { Transition, "From Federalism, Chinese Style, } \\
\text { to Privatization Chinese Style," } 7(1), 1999, \\
\text { pgs. } 103-31\end{array}$ & $\begin{array}{l}\text { Yuanzheng Cao, Yingyi Qian, and Barry R. } \\
\text { Weingast }\end{array}$ & December 1997 \\
\hline $\begin{array}{l}\text { No. 125: Market Discipline in Conglomerate } \\
\text { Banks: Is an Internal Allocation of Cost of } \\
\text { Capital Necessary as Incentive Device? } \\
\text { Forthcoming in Financial Systems in } \\
\text { Transition: The Design of Financial Systems } \\
\text { in Central Europe eds. Anna Meyendorff and } \\
\text { Anjan Thakor. }\end{array}$ & Arnoud W. A. Boot and Anjolein Schmeits & November 1997 \\
\hline $\begin{array}{l}\text { No. 124: Financial Discipline in the } \\
\text { Enterprise Sector in Transition Countries: } \\
\text { How Does China Compare? }\end{array}$ & Shumei Gao and Mark E. Schaffer & February 1998 \\
\hline $\begin{array}{l}\text { No. 123: Considerations of an Emerging } \\
\text { Marketplace: Managers, Perceptions in the } \\
\text { Southern African Economic Community }\end{array}$ & Brent Chrite and David Hudson & February 1998 \\
\hline $\begin{array}{l}\text { No. 122: A Model of the Informal Economy in } \\
\text { Transition Economies }\end{array}$ & $\begin{array}{l}\text { Simon Commander and Andrei } \\
\text { Tolstopiatenko }\end{array}$ & November 1997 \\
\hline $\begin{array}{l}\text { No. 121: Local Labour Market Dynamics in } \\
\text { the Czech and Slovak Republics }\end{array}$ & Peter Huber and Andreas Worgotter & November 1997 \\
\hline $\begin{array}{l}\text { No. 121: Local Labour Market Dynamics in } \\
\text { the Czech and Slovak Republics }\end{array}$ & Peter Huber and Andreas Worgotter & November 1997 \\
\hline $\begin{array}{l}\text { No. 119: Institutional Upheaval and Company } \\
\text { Transformation in Emerging Market } \\
\text { Economies }\end{array}$ & Karen L. Newman & March 1998 \\
\hline
\end{tabular}


William Davidson Institute Working Paper Number 320

\begin{tabular}{|c|c|c|}
\hline $\begin{array}{l}\text { No. 118: Industrial Decline and Labor } \\
\text { Reallocation in Romania }\end{array}$ & John S. Earle & October 1997 \\
\hline $\begin{array}{l}\text { No. 117: Notes for an Essay on the Soft } \\
\text { Budget Constraint }\end{array}$ & Lorand Ambrus-Lakatos & January 1997 \\
\hline $\begin{array}{l}\text { No. 116: Labor Demand During Transition in } \\
\text { Hungary }\end{array}$ & Gabor Korosi & October 1997 \\
\hline $\begin{array}{l}\text { No. 115: Enterprise Performance and } \\
\text { Managers' Profiles }\end{array}$ & Simeon Djankov and Stijn Claessens & December 1997 \\
\hline $\begin{array}{l}\text { No. } 114 b \text { Employment and Wages in } \\
\text { Enterprises under Communism and in } \\
\text { Transition: Evidence From Central Europe } \\
\text { and Russia }\end{array}$ & Swati Basu, Saul Estrin, and Jan Svejnar & April 2000 \\
\hline $\begin{array}{l}\text { No. 114: Employment and Wage Behavior of } \\
\text { Enterprises in Transitional Economies }\end{array}$ & Swati Basu, Saul Estrin, and Jan Svejnar & October 1997 \\
\hline $\begin{array}{l}\text { No. 113: Preliminary Evidence on Active } \\
\text { Labor Programs' Impact in Hungary and } \\
\text { Poland }\end{array}$ & Christopher J. O’Leary & October 1997 \\
\hline $\begin{array}{l}\text { No. 111: Unemployment Benefits and } \\
\text { Incentives in Hungary: New Evidence }\end{array}$ & Joachim Wolff & October 1997 \\
\hline $\begin{array}{l}\text { No. 110: Published in: Empirical Economics, } \\
\text { "Long-Term Unemployment, Unemployment } \\
\text { Benefits and Social Assistance: The Polish } \\
\text { Experience" Empirical-Economics; 23(1-2), } \\
\text { 1998, pages 55-85. }\end{array}$ & Marek Gora and Christoph M. Schmidt & April 1997 \\
\hline $\begin{array}{l}\text { No. } 109 \text { Published in: Industrial and Labor } \\
\text { Relations Review, "Markets for Communist } \\
\text { Human Capital: Returns to Education and } \\
\text { Experience in Post-Communist Czech } \\
\text { Republic and Slovakia." Vol. 51, No. 3, April } \\
\text { 1998, pp. 401-423. }\end{array}$ & Robert S. Chase & October 1997 \\
\hline $\begin{array}{l}\text { No. 107: The Worker-Firm Matching in the } \\
\text { Transition: (Why) Are the Czechs More } \\
\text { Successful Than Others? }\end{array}$ & $\begin{array}{l}\text { Daniel Münich, Jan Svejnar, and } \\
\text { Katherine Terrell }\end{array}$ & October 1997 \\
\hline $\begin{array}{l}\text { No. } 106 \text { Published in: Journal of } \\
\text { Comparative Economics, "Job Creation, Job } \\
\text { Destruction and Growth of Newly Established, } \\
\text { Privatized and State-Owned Enterprises in } \\
\text { Transition Economies: Survey Evidence from } \\
\text { Bulgaria, Hungary, and Romania," Vol. 26, } \\
\text { No.3, September 1998, pp. 429-445. }\end{array}$ & Valentijn Bilsen and Jozef Konings & September 1998 \\
\hline $\begin{array}{l}\text { No. 105: Getting Behind the East-West } \\
\text { [German] Wage Differential: Theory and } \\
\text { Evidence }\end{array}$ & Michael Burda and Christoph Schmidt & May 1997 \\
\hline $\begin{array}{l}\text { No. 104: The Birth of the "Wage Curve" in } \\
\text { Hungary, 1989-95 }\end{array}$ & Gabor Kertesi and Janos Kollo & October 1997 \\
\hline $\begin{array}{l}\text { No. 103: Published in: Journal of } \\
\text { Comparative Economics, "Grime and } \\
\text { Punishment: Job Insecurity and Wage Arrears } \\
\text { in the Russian Federation" 27, 595-617 } \\
\text { (1999). }\end{array}$ & $\begin{array}{l}\text { Hartmut Lehmann, Jonathan Wadsworth, } \\
\text { and Alessandro Acquisti }\end{array}$ & October 1997 \\
\hline No. 102: Social Networks in Transition & $\begin{array}{l}\text { Lorena Barberia, Simon Johnson, and } \\
\text { Daniel Kaufmann }\end{array}$ & October 1997 \\
\hline
\end{tabular}




\begin{tabular}{|c|c|c|}
\hline $\begin{array}{l}\text { No. 101: Depreciation and Russian Corporate } \\
\text { Finance: A Pragmatic Approach to Surviving } \\
\text { the Transition }\end{array}$ & Susan J. Linz & November 1997 \\
\hline No. 100: Romanian Financial System Reform & Anna Meyendorff and Anjan V. Thakor & November 1997 \\
\hline $\begin{array}{l}\text { No. 99: Proceedings of the Conference on } \\
\text { Strategic Alliances in Transitional Economies, } \\
\text { held May 20, } 1997 \text { at the Davidson Institute }\end{array}$ & Edited by Cynthia Koch & May 1997 \\
\hline $\begin{array}{l}\text { No. 98: Institutions, Strain and the } \\
\text { Underground Economy }\end{array}$ & Daniel Daianu and Lucian Albu & November 1997 \\
\hline $\begin{array}{l}\text { No. 97: Structure and Strain in Explaining } \\
\text { Inter-Enterprise Arrears }\end{array}$ & Daniel Daianu & November 1997 \\
\hline $\begin{array}{l}\text { No. 96: Resource Misallocation and Strain: } \\
\text { Explaining Shocks in Post-Command } \\
\text { Economies }\end{array}$ & Daniel Daianu & November 1997 \\
\hline $\begin{array}{l}\text { No. 95: Published in: Finance-a-Uver, } \\
\text { "Czech Money Market: Emerging Links } \\
\text { Among Interest Rates." 48(2) } 1998 \text { pp. 99- } \\
\text { 109. }\end{array}$ & Jan Hanousek and Evzen Kocenda & November 1997 \\
\hline $\begin{array}{l}\text { No. 94: Pre-Reform Industry and the } \\
\text { State Monopsony in China }\end{array}$ & Xiao-Yuan Dong and Louis Putterman & October 1997 \\
\hline $\begin{array}{l}\text { No. 93: China's State-Owned Enterprises } \\
\text { In the First Reform Decade: } \\
\text { An Analysis of a Declining Monopsony }\end{array}$ & Xiao-Yuan Dong and Louis Putterman & October 1997 \\
\hline $\begin{array}{l}\text { No. 92: Expatriate Management in the Czech } \\
\text { Republic }\end{array}$ & Richard B. Peterson & September 1997 \\
\hline $\begin{array}{l}\text { No. 91: China and the Idea of Economic } \\
\text { Reform }\end{array}$ & Thomas G. Rawski & April 1997 \\
\hline $\begin{array}{l}\text { No. } 90 \text { Published in: China Economic } \\
\text { Review, "China's State Enterprise Reform: An } \\
\text { Overseas Perspective." Vol. 8, Spring 1997, } \\
\text { pp. 89-98. }\end{array}$ & Thomas G. Rawski & July 1997 \\
\hline $\begin{array}{l}\text { No. 89: The Economic Determinants of } \\
\text { Internal Migration Flows in Russia During } \\
\text { Transition }\end{array}$ & Annette N. Brown & July 1997 \\
\hline $\begin{array}{l}\text { No. 88: Gender Wage Gaps in China's Labor } \\
\text { Market: Size, Structure, Trends }\end{array}$ & $\begin{array}{l}\text { Margaret Maurer-Fazio, Thomas G. } \\
\text { Rawski, and Wei Zhang }\end{array}$ & July 1997 \\
\hline $\begin{array}{l}\text { No. 87: Privatisation in Central and Eastern } \\
\text { Europe }\end{array}$ & Saul Estrin & June 1997 \\
\hline $\begin{array}{l}\text { No. 86: Published in : Economics of } \\
\text { Transition, "The Effect of Privatization on } \\
\text { Wealth Distribution in Russia." v. 7, no. 2, } \\
\text { 1999, pp. 449-65 }\end{array}$ & Michael Alexeev & February 1998 \\
\hline $\begin{array}{l}\text { No. 85: Was Privatization in Eastern Germany } \\
\text { a Special Case? Some Lessons from the } \\
\text { Treuhand }\end{array}$ & Uwe Siegmund & September 1997 \\
\hline No. 84: Start-ups and Transition & Daniel M. Berkowitz and David J. Cooper & September 1997 \\
\hline $\begin{array}{l}\text { No. 83: Which Enterprises (Believe They) } \\
\text { Have Soft Budgets after Mass Privatization? } \\
\text { Evidence from Mongolia }\end{array}$ & $\begin{array}{l}\text { James Anderson, Georges Korsun, and } \\
\text { Peter Murrell }\end{array}$ & October 1997 \\
\hline $\begin{array}{l}\text { No. 82: Published in: European Economic } \\
\text { Review, "Unemployment Dynamics and the } \\
\text { Restructuring of the Slovak Unemployment } \\
\text { Benefit System.” April, 1997. }\end{array}$ & Martina Lubyova and Jan C. van Ours & June 1997 \\
\hline
\end{tabular}


William Davidson Institute Working Paper Number 320

\begin{tabular}{|c|c|c|}
\hline $\begin{array}{l}\text { No. 81: Determinants of Unemployment } \\
\text { Duration in Russia }\end{array}$ & Mark C. Foley & August 1997 \\
\hline $\begin{array}{l}\text { No. 80: The Many Faces of Information } \\
\text { Disclosure }\end{array}$ & Arnoud W.A. Boot and Anjan V. Thakor & October 1997 \\
\hline $\begin{array}{l}\text { No. 79: Published in: Journal of Finance, } \\
\text { "Foreign Speculators and Emerging Equity } \\
\text { Markets."v.22, iss. 2, 2000, pp. 565-613 }\end{array}$ & Geert Bekaert and Campbell R. Harvey & August 1997 \\
\hline $\begin{array}{l}\text { No. 78: The Relationship Between Economic } \\
\text { Factors and Equity Markets in Central Europe }\end{array}$ & Jan Hanousek and Randall K. Filer & June 1997 \\
\hline $\begin{array}{l}\text { No. } 77 \text { Published in: Economics of } \\
\text { Transition, "A Gini Decomposition Analysis } \\
\text { of Inequality in the Czech and Slovak } \\
\text { Republics During the Transition," Vol. 6, } \\
\text { No.1, May 1998, pp. 23-46. }\end{array}$ & Thesia I. Garner and Katherine Terrell & May 1998 \\
\hline $\begin{array}{l}\text { No. 76: Chinese Enterprise Reform as a } \\
\text { Market Process }\end{array}$ & Gary H. Jefferson and Thomas G. Rawski & June 1997 \\
\hline $\begin{array}{l}\text { No. } 75 b: \text { Test of Permanent Income } \\
\text { Hypothesis on Czech Voucher Privatization }\end{array}$ & Jan Hanousek and Zdenek Tima & October 1997 \\
\hline $\begin{array}{l}\text { No. 74: Determinants of Performance of } \\
\text { Manufacturing Firms in Seven European } \\
\text { Transition Economies }\end{array}$ & $\begin{array}{l}\text { Stijn Claessens, Simeon Djankov, and } \\
\text { Gerhard Pohl }\end{array}$ & February 1997 \\
\hline $\begin{array}{l}\text { No. } 73 \text { Published in: Economics of } \\
\text { Transition, "The Restructuring of Large } \\
\text { Firms in Slovak Republic." Vol. 6, No. 1, May } \\
\text { 1998, pp. 67-85 }\end{array}$ & Simeon Djankov and Gerhard Pohl & May 1998 \\
\hline $\begin{array}{l}\text { No. 72: Law, Relationships, and Private } \\
\text { Enforcement: Transactional Strategies of } \\
\text { Russian Enterprises }\end{array}$ & $\begin{array}{l}\text { Kathryn Hendley, Peter Murrell, and } \\
\text { Randi Ryterman }\end{array}$ & November 1998 \\
\hline $\begin{array}{l}\text { No. 71: Giving Credit Where Credit Is Due: } \\
\text { The Changing Role of Rural Financial } \\
\text { Institutions in China }\end{array}$ & Albert Park, Loren Brandt, and John Giles & March 1997 \\
\hline $\begin{array}{l}\text { No. 70: Privatization Versus Competition: } \\
\text { Changing Enterprise Behavior in Russia }\end{array}$ & John S. Earle and Saul Estrin & Spring 1997 \\
\hline $\begin{array}{l}\text { No. 69: Russian Managers under Storm: } \\
\text { Explicit Reality and Implicit Leadership } \\
\text { Theories (A Pilot Exploration) }\end{array}$ & Igor Gurkov & October 1998 \\
\hline $\begin{array}{l}\text { No. 68: The Political Economy of Central- } \\
\text { Local Relations in China: Inflation and } \\
\text { Investment Controls During the Reform Era }\end{array}$ & Yasheng Huang & Spring 1997 \\
\hline $\begin{array}{l}\text { No. 67: Between Two Coordination Failures: } \\
\text { Automotive Industrial Policy in China with a } \\
\text { Comparison to Korea }\end{array}$ & Yasheng Huang & Spring 1997 \\
\hline $\begin{array}{l}\text { No. } 66 \text { Published in: Post-Soviet Geography } \\
\text { and Economics, “Red Executives in Russia's } \\
\text { Transition Economy." Vol. 27, No. 10, } \\
\text { November 1996, pp. 633-651. }\end{array}$ & Susan J. Linz & January 1997 \\
\hline $\begin{array}{l}\text { No. } 65 \text { Published in: Industrial and } \\
\text { Corporate Change, "On the Sequencing of } \\
\text { Privatization in Transition Economies." Vol. } \\
\text { 7, No. 1, 1998. }\end{array}$ & Gautam Ahuja and Sumit K. Majumdar & April 1997 \\
\hline
\end{tabular}




\begin{tabular}{|c|c|c|}
\hline $\begin{array}{l}\text { No. 64: Published in: Journal of Law and } \\
\text { Economics, "Foreign Ownership and } \\
\text { Profitability: Property Rights, Control and the } \\
\text { Performance of Firms in Indian Industry" } \\
\text { 42(1), April 1999, pp. 209-38. }\end{array}$ & $\begin{array}{l}\text { Pradeep K. Chhibber and Sumit K. } \\
\text { Majumdar }\end{array}$ & April 1997 \\
\hline $\begin{array}{l}\text { No. 63: How Taxing Is Corruption on } \\
\text { International Investors? }\end{array}$ & Shang-Jin Wei & February 1997 \\
\hline $\begin{array}{l}\text { No. 62: What Can We Learn from the } \\
\text { Experience of Transitional Economies with } \\
\text { Labour Market Policies? } \\
\text { No. 61: Published in: Accounting } \\
\text { Organizations and Society, "Economic } \\
\text { Transition, Strategy and the Evolution of } \\
\text { Management Accounting Practices: The Case } \\
\text { of India" 24(5,6), Jul/Aug 1999, pp. 379-412. }\end{array}$ & $\begin{array}{l}\text { Tito Boeri } \\
\text { Shannon W. Anderson and William N. } \\
\text { Lanen }\end{array}$ & 1997 \\
\hline $\begin{array}{l}\text { No. 60a: Enterprise Investment During the } \\
\text { Transition: Evidence from Czech Panel Data }\end{array}$ & Lubomír Lizal and Jan Svejnar & December 1997 \\
\hline $\begin{array}{l}\text { No. 59: Published in: Journal of Law, } \\
\text { Economics, and Organization, "Institutional } \\
\text { Environment, Community Government, and } \\
\text { Corporate Governance: Understanding } \\
\text { China's Township-Village Enterprises." } \\
\text { 14(1), April 1998, pages 1-23 }\end{array}$ & Jiahua Che and Yingyi Qian & April 1997 \\
\hline $\begin{array}{l}\text { No. 58: From the Grabbing Hand to the } \\
\text { Helping Hand }\end{array}$ & Jiahua Che & June 2000 \\
\hline $\begin{array}{l}\text { No. 57: Published in: Brookings Papers on } \\
\text { Economic Activity, “The Unofficial Economy } \\
\text { in Transition." 1: 1998. }\end{array}$ & $\begin{array}{l}\text { Simon Johnson, Daniel Kaufmann, and } \\
\text { Andrei Schleifer }\end{array}$ & June 1997 \\
\hline $\begin{array}{l}\text { No. 56: Taxes and Government Incentives: } \\
\text { Eastern Europe vs. China }\end{array}$ & Roger H. Gordon and David D. Li & April 1997 \\
\hline No. 55: Corruption and Reform & Susanto Basu and David Li & June 1996 \\
\hline $\begin{array}{l}\text { No. 54: Decentralization and the } \\
\text { Macroeconomic Consequences of } \\
\text { Commitment to State-Owned Firms }\end{array}$ & Loren Brandt and Xiaodong Zhu & June 1997 \\
\hline $\begin{array}{l}\text { No. 53: Published in: The International } \\
\text { Journal of Industrial Organization, } \\
\text { "Competitive Shocks and Industrial Structure: } \\
\text { The Case of Polish Manufacturing." August, } \\
\text { 1999. . }\end{array}$ & Pankaj Ghemawat and Robert E. Kennedy & May 1997 \\
\hline $\begin{array}{l}\text { No. 52: Published in: The Quarterly Journal } \\
\text { of Economics, "Insecure Property Rights and } \\
\text { Government Ownership of Firms." May, } \\
\text { 1998. }\end{array}$ & Jiahua Che and Yingyi Qian & May 1997 \\
\hline $\begin{array}{l}\text { No. 51: Incentives, Scale Economies, and } \\
\text { Organizational Form }\end{array}$ & $\begin{array}{l}\text { Eric Maskin, Yingyi Qian, and Chenggang } \\
X u\end{array}$ & May 1997 \\
\hline $\begin{array}{l}\text { No. 50: Published in: Post-Soviet-Affairs, } \\
\text { "End of the Tunnel? The Effects of Financial } \\
\text { Stabilization in Russia" April-June 1997, } \\
\text { pages 105-33 }\end{array}$ & $\begin{array}{l}\text { Barry W. Ickes, Peter Murrell, and Randi } \\
\text { Ryterman }\end{array}$ & March 1997 \\
\hline $\begin{array}{l}\text { No. 49: The Evolution of Bank Credit Quality } \\
\text { in Transition: Theory and Evidence from } \\
\text { Romania }\end{array}$ & Enrico C. Perotti and Octavian Carare & October 1996 \\
\hline
\end{tabular}


William Davidson Institute Working Paper Number 320

\begin{tabular}{|c|c|c|}
\hline $\begin{array}{l}\text { No. 48: Where Do the Leaders Trade? } \\
\text { Information Revelation and Interactions } \\
\text { Between the Segments of Czech Capital } \\
\text { Markets }\end{array}$ & Jan Hanousek and Libor Nemecek & May 1997 \\
\hline $\begin{array}{l}\text { No. 47: Firms' Heterogeneity in Transition: } \\
\text { Evidence from a Polish Panel Data Set }\end{array}$ & Irena Grosfeld and Jean-François Nivet & May 1997 \\
\hline $\begin{array}{l}\text { No. 46: Strategic Creditor Passivity, } \\
\text { Regulation, and Bank Bailouts }\end{array}$ & Janet Mitchell & May 1997 \\
\hline $\begin{array}{l}\text { No. 45a: Decentralization in Transition } \\
\text { Economies: A Tragedy of the Commons? }\end{array}$ & Daniel M. Berkowitz and Wei Li & September 1997 \\
\hline $\begin{array}{l}\text { No. 44a: The Information Content of Stock } \\
\text { Markets: Why do Emerging Markets have } \\
\text { Synchronous Stock Price Movements? } \\
\text { (forthcoming in the Journal of Financial } \\
\text { Economics). }\end{array}$ & $\begin{array}{l}\text { Randall Morck, Bernard Yeung, and } \\
\text { Wayne Yu }\end{array}$ & February 1999 \\
\hline $\begin{array}{l}\text { No. 43: Agency in Project Screening and } \\
\text { Termination Decisions: Why Is Good Money } \\
\text { Thrown After Bad? }\end{array}$ & Chong-en Bai and Yijiang Wang & May 1997 \\
\hline $\begin{array}{l}\text { No. 42: Published in: Economics of } \\
\text { Transition, "Channels of Redistribution: } \\
\text { Inequality and Poverty in the Russian } \\
\text { Transition." Vol. } 7 \text { (2) } 1999 .\end{array}$ & $\begin{array}{l}\text { Simon Commander, Andrei Tolstopiatenko, } \\
\text { and Ruslan Yemtsov }\end{array}$ & May 1997 \\
\hline $\begin{array}{l}\text { No. 41: Published in: Economics of } \\
\text { Transition, “Labour Market Characteristics } \\
\text { and Profitability: Econometric Analysis of } \\
\text { Hungarian Exporting Firms, 1986-1995” } \\
6(1), \text { May 1998, pages 145-62 }\end{array}$ & László Halpern and Gabor Korosi & May 1997 \\
\hline $\begin{array}{l}\text { No. 40: Published in: the Harvard Law } \\
\text { Review, "The Tragedy of the Anticommons: } \\
\text { Property in the Transition from Marx to } \\
\text { Markets." January 1998. }\end{array}$ & Michael Heller & February 1997 \\
\hline $\begin{array}{l}\text { No. 39: Privatization and Managerial } \\
\text { Efficiency }\end{array}$ & Olivier Debande and Guido Friebel & May 1997 \\
\hline $\begin{array}{l}\text { No. } 38 \text { Published in: The Quarterly Journal } \\
\text { of Economics, “Disorganization.” Vol. 112, } \\
\text { No. 4, November 1997, pp. 1091-1126. }\end{array}$ & Olivier Blanchard and Michael Kremer & January 1997 \\
\hline $\begin{array}{l}\text { No. 37: Published in: Economics of } \\
\text { Transition, "Transition and the Output Fall.", } \\
\text { 7(1), 1999, pages 1-28. }\end{array}$ & Gérard Roland and Thierry Verdier & March 1997 \\
\hline $\begin{array}{l}\text { No. 36: Restructuring an Industry During } \\
\text { Transition: A Two-Period Model }\end{array}$ & Richard Ericson & September 1996 \\
\hline $\begin{array}{l}\text { No. 34: The East-West Joint Venture: BC } \\
\text { Torsion Case Study }\end{array}$ & Sonia Ferencikova and Vern Terpstra & December 1998 \\
\hline $\begin{array}{l}\text { No. } 33 \text { Published in: Journal of Comparative } \\
\text { Economics, “Quantifying Price Liberalization } \\
\text { in Russia." Vol. 26, No. 4, December 1998, } \\
\text { pp. } 735-737 .\end{array}$ & $\begin{array}{l}\text { Daniel Berkowitz, David DeJong, and } \\
\text { Steven Husted }\end{array}$ & December 1998 \\
\hline $\begin{array}{l}\text { No. 32: What Can North Korea Learn from } \\
\text { China's Market Reforms? }\end{array}$ & John McMillan & September 1996 \\
\hline $\begin{array}{l}\text { No. 31: Published in : China-Economic- } \\
\text { Review, "Towards a Model of China as a } \\
\text { Partially Reformed Developing Economy } \\
\text { Under a Semifederalist Government.", 9(1), } \\
\text { Spring 1998, pages 1-23. }\end{array}$ & Yijiang Wang and Chun Chang & March 1997 \\
\hline
\end{tabular}




\begin{tabular}{|c|c|c|}
\hline $\begin{array}{l}\text { No. 30: Convergence in Output in Transition } \\
\text { Economies: Central and Eastern Europe, } \\
\text { 1970-1995 }\end{array}$ & Saul Estrin and Giovanni Urga & February 1997 \\
\hline $\begin{array}{l}\text { No. 29: Published in: Economics of } \\
\text { Transition, “Altered Band and Exchange } \\
\text { Volatility." Volume 6, no. 1, 1998, 173-181. }\end{array}$ & Evzen Kocenda & March 1997 \\
\hline $\begin{array}{l}\text { No. 28: Published in: Quarterly Journal of } \\
\text { Economics, "Public Versus Private } \\
\text { Ownership of Firms: Evidence from Rural } \\
\text { China." Volume 113, no. 3, August 1998, 773- } \\
\text { 808. }\end{array}$ & Hehui Jin and Yingyi Qian & January 1997 \\
\hline $\begin{array}{l}\text { No. 27: East-West Joint Ventures in a } \\
\text { Transitional Economy: The Case of Slovakia }\end{array}$ & Sonia Ferencikova & March 1997 \\
\hline $\begin{array}{l}\text { No. 26: Published in Economic Analysis } \\
\text { "Behavior of a Slovenian Firm in Transition" } \\
\text { Vol. 1, no. 1, 1998, 57-73. }\end{array}$ & Janez Prasnikar & February 1997 \\
\hline $\begin{array}{l}\text { No. 25: Cultural Encounters and Claims to } \\
\text { Expertise in Postcommunist Capitalism }\end{array}$ & Michael D. Kennedy & February 1997 \\
\hline $\begin{array}{l}\text { No. 24: ZVU a.s.: Investment Funds on the } \\
\text { Board of Directors of an Engineering Giant }\end{array}$ & Tory Wolff & August 1995 \\
\hline $\begin{array}{l}\text { No. 23: The Role of Investment Funds in the } \\
\text { Czech Republic (joint publication with Czech } \\
\text { Management Center) }\end{array}$ & Dusan Triska & June 1996 \\
\hline $\begin{array}{l}\text { No. 22: Czech Investment Fund Industry: } \\
\text { Development and Behaviour (joint publication } \\
\text { with Czech Management Center) }\end{array}$ & Richard Podpiera & May 1996 \\
\hline $\begin{array}{l}\text { No. 21: Restructuring of Czech Firms: An } \\
\text { Example of Gama, a.s. (joint publication with } \\
\text { Czech Management Center) }\end{array}$ & Antonin Bulin & June 1996 \\
\hline $\begin{array}{l}\text { No. 20: YSE Funds: A Story of Czech } \\
\text { Investment Funds (joint publication with } \\
\text { Czech Management Center) }\end{array}$ & Michal Otradovec & November 1995 \\
\hline $\begin{array}{l}\text { No. 19: První Investicni a.s., The First } \\
\text { Investment Corporation (joint publication } \\
\text { with Czech Management Center) }\end{array}$ & Jaroslav Jirasek & August 1995 \\
\hline $\begin{array}{l}\text { No. 18: PPF a.s., The First Private Investment } \\
\text { Fund (joint publication with Czech } \\
\text { Management Center) }\end{array}$ & Michal Otradovec & November 1995 \\
\hline $\begin{array}{l}\text { No. } 17 \text { Published in: Post-Soviet Geography } \\
\text { and Economics, “Russia's Managers in } \\
\text { Transition: Pilferers or Paladins?" Vol. 37, } \\
\text { o.7 (September 1996), pp. 397-426. }\end{array}$ & Susan J. Linz and Gary Krueger & November 1996 \\
\hline $\begin{array}{l}\text { No. 16: Banks in Transition-Investment } \\
\text { Opportunities in Central Europe and Russia } \\
\text { Edited Transcript from } 31 \text { May } 1996 \\
\text { Conference in New York City }\end{array}$ & $\begin{array}{l}\text { With commentary and edited by Anna } \\
\text { Meyendorff }\end{array}$ & January 1997 \\
\hline $\begin{array}{l}\text { No. 15: Marketing in Transitional Economies: } \\
\text { Edited Transcript \& Papers from } 1 \text { April } 1996 \\
\text { Conference in Ann Arbor, Michigan }\end{array}$ & Compiled by The Davidson Institute & December 1996 \\
\hline $\begin{array}{l}\text { No. 14: Pensions in the Former Soviet Bloc: } \\
\text { Problems and Solutions. Published by } \\
\text { Council on Foreign Relations. "The Coming } \\
\text { Global Pension Crisis" New York, } 1997\end{array}$ & Jan Svejnar & November 1996 \\
\hline
\end{tabular}


William Davidson Institute Working Paper Number 320

\begin{tabular}{|c|c|c|}
\hline $\begin{array}{l}\text { No. 13: Enterprise Restructuring and } \\
\text { Performance in the Transition. Forthcoming } \\
\text { in Financial Systems in Transition: The } \\
\text { Design of Financial Systems in Central } \\
\text { Europe eds. Anna Meyendorff and Anjan } \\
\text { Thakor. }\end{array}$ & $\begin{array}{l}\text { Lubomir Lizal, Miroslav Singer, and Jan } \\
\text { Svejnar }\end{array}$ & December 1996 \\
\hline $\begin{array}{l}\text { No. } 12 \text { Published in: Journal of International } \\
\text { Marketing, “Executive Insights: Marketing } \\
\text { Issues and Challenges in Transitional } \\
\text { Economies." Vol. 5, No. 4, 1997, pp. 95-114. } \\
\text { Also published in: Marketing Issues in } \\
\text { Transitional Economies ed. Rajeev Batra. }\end{array}$ & Rajeev Batra & April 1997 \\
\hline $\begin{array}{l}\text { No. 11: Worker Trust and System } \\
\text { Vulnerability in the Transition from Socialism } \\
\text { to Capitalism }\end{array}$ & Andrew Schotter & August 1996 \\
\hline $\begin{array}{l}\text { No. } 10 \text { Published in: Comparative Economic } \\
\text { Studies, "Russian Firms in Transition: } \\
\text { Champions, Challengers, and Chaff." Vol. } \\
\text { 39, No.2, Summer 1997, pp. 1-36. }\end{array}$ & Susan J. Linz & July 1996 \\
\hline $\begin{array}{l}\text { No. 9: Corporate Debt Crisis and Bankruptcy } \\
\text { Law During the Transition: The Case of China }\end{array}$ & David D. Li and Shan Li & December 1995 \\
\hline $\begin{array}{l}\text { No. } 8 \text { Published in: Journal of Comparative } \\
\text { Economics, “A Theory of Ambiguous } \\
\text { Property Rights in Transition Economies: The } \\
\text { Case of the Chinese Non-State Sector." Vol. } \\
23, \text { No. 1, August 1996, pp. 1-19. }\end{array}$ & David D. Li & June 1996 \\
\hline $\begin{array}{l}\text { No. 7: The Foreign Economic Contract Law of } \\
\text { China: Cases and Analysis }\end{array}$ & Dong-lai Li & June 1993 \\
\hline $\begin{array}{l}\text { No. 3: Bank Privatization in Hungary and the } \\
\text { Magyar Kulkereskedelmi Bank Transaction }\end{array}$ & Roger Kormendi and Karen Schnatterly & May 1996 \\
\hline $\begin{array}{l}\text { Replacing Nos. 1-2 \& 4-6: Journal of } \\
\text { Comparative Economics Symposium on } \\
\text { “Bank Privatization in Central Europe and } \\
\text { Russia." Vol. 25, No. 1, August } 1997 .\end{array}$ & $\begin{array}{l}\text { No. } 1 \text { "Bank Privatization in Transitional } \\
\text { Economies" by Roger Kormendi and } \\
\text { Edward Snyder. No. } 2 \text { "Transactional } \\
\text { Structures of Bank Privatizations in } \\
\text { Central Europe and Russia” by Anna } \\
\text { Meyendorff and Edward A. Snyder. No. } 4 \\
\text { "Bank Privatization in Poland: The Case } \\
\text { of Bank Slaski" by Jeffery Abarbaness and } \\
\text { John Bonin. No. } 5 \text { "Bank Privatization in } \\
\text { Post-Communist Russia: The Case of } \\
\text { Zhilsotsbank" by Jeffery Abarbanell and } \\
\text { Anna Meyendorff and No. } 6 \text { "” The Czech } \\
\text { Republic's Commercial Bank: Komercni } \\
\text { Banka" by Edward A. Snyder and Roger } \\
\text { C. Kormendi. }\end{array}$ & August 1997 \\
\hline
\end{tabular}

